\title{
EXPERIMENTAL STUDY ON FAILURE OF PLAIN CONCRETE UNDER COMBINED STRESSES
}

\author{
Part 3
}

\author{
by Dr. Yoshikatsu Tsuboi* \& Yasuyoshi Suenaga** \\ Members, A.I.J.
}

\section{Scope of Investigation}

The objective of this study is to formulate the law of failure on plain concrete under combined stresses and also to apply the failure criterion to the determination of shearing strength of reinforced concrete members such as beams and columns.

This study consists of two parts.

1) The experiment on compression combined with tensiones which are at right angles was tested to failure under the action of axial compression applied by a testing machine together with circumferential tension developed by means of internal water pressure to a hollow concrete cylinder test piece.

2) The experiment on shear combined with axial compression was carried out by applying axial compressive load and torsional load to the hollow concrete cylinder.

The test on the two tensions at right angles to each other was made as a preliminary test by applying axial tensile load and internal water pressure to the hollow concrete cylinder.

The parameter in this test is the changes in the strength of concrete and the changes in the ratio of stresses combined. Distribution of strain was constantly measured by W.S.G. while the stresses were combined. We have acquired some knowledge of loading apparatus and test procedures through this test. In the test where compression and torsion were applied to the specimen at the same time, the torsion angle was measured for investigating the influences from the Modulus of rigidity of concrete as well as from the frictional resistance to rotation of the bearing block.

The data obtained from this test is analyzed by the octahedral stress theory. The method of application of the failure theory against shearing resistance, which is the second objective of this study, shall be treated later.

\section{Introduction}

Since the failure of structural elements generally occurs under conditions of complicated combined stresses, it is. therefore very important for us to understand in full the criteria of failure of concrete members of frame work under combined stresses. Especially in recent years, this has become more and more important in proportion to the advancements made in designing methods of concrete members of frame work. Reinforced concrete structures such as plates, shell constructions, arch-dams, beams, columns and prestress concrete structures generally fail under complicated stress conditions.

In considering the mechanism of failure of reinforced or prestressed concrete structures, it has often been stated that the presence of reinforcement or prestress alters the nature of the material and therefore changes the criteria of failure. Indeed, the bond between concrete and its reinforcement and the deformation or fracture of steel play an important role in the mechanism of failure of reinforced concrete structures. But conditions producing local failure in concrete are considered essentially the same, regardless of whether the concrete is plain or reinforced. Therefore, knowledge of the conditions producing local failure in plain concrete would lead to understanding of the failure mechanism in reinforced or prestressed concrete structural elements.

There have been made many studies regarding the criteria of failure. However, it is my impression that the laws of failure made public so far combined stresses, whether derived from theoretical studies or experiments are applicable only to multi-crystallized metals.

Investigation of failure in plain concrete is complicated by the nonhomogeneity and nonisotropy of the material. Therefore even in the few studies made so far, the correlation between experimental data and failure theory has. not yet been clarified. Besides, the existing studies have always been based on only the test of uniaxial, biaxial and triaxial compressions and that of bending and torsion. It is only recently that experiments of combined stresses. between shear and torsion have been reported.

In this study, 140 hollow concrete cylinders were tested in order to gain clear test results regarding the failure of concrete under combined stresses.

Experimental data of the combined stresses are shown in a correlation expressed by a simple equation between octahedral normal stresses and shearing stresses at time of failure. A comparison with data of previous experiments. is also shown.

\section{Studies in the Past}

So far, only a few studies ${ }^{1,2)}$ on brittle materials like concrete have been made. This is because, a) Concrete does not distinctly show the existence of yield point. b) Tension and compression are different in

* Prof., Univ. of Tokyo. Director of Research.

** Postgraduate Student, Univ. of Tokyo. Person in Charge of Research. 
their behavior. c) It is very difficult to conduct experiments under conditions of combined stress.

The initial studies of brittle materials were made by W.A. Scoble ${ }^{3)}$ in 1910 and T.V. Karman ${ }^{4}$ in 1912. They chose cast iron, marble, sand stone as their test mediums. As for the study of concrete, we can mention the work of R. Ros and A. Eichinger ${ }^{5)}$ in 1926. These are considered all of the empirical studies made in the early years.

Initial theoretical study in this field was made by A. Griffith ${ }^{6)}$, on Englishman, in 1920 . Subsequent studies were made by D. Fisher, N. Sydney ${ }^{7}$ and H.J. Cowan ${ }^{8)}$, also Englishman.

In other countries similar studies were made by A. Brandtzaeg ${ }^{9}$, A. Freudenthal ${ }^{10)}$, D. McKenry ${ }^{11)}$, and B. Bresler ${ }^{12}$ in America, by A. Leon ${ }^{13)}$, F. Schleicher ${ }^{14)}$ and C. Torre ${ }^{15)}$ in Germany, and by G. Wastlund ${ }^{16)}$ and H. Nylander ${ }^{17}$ ) in Sweden. In the Soviet Union also, the study of this field has begun to be regarded more important as the number of sheet-wall concrete structures have increased. V.A. Sveshikova and A.K. Malmeister, K.K. Shkerbelis ${ }^{18)}$ have left many experimental results in this field.

However, these researches have not yet succeeded in discovering either the mode of failure or the decisive law of failure applicable to any sort of material under any stress condition.

\section{Test Program}

There are three types of combined stress, i.e. Uni-axial stress, Biaxial stress, and Triaxial stress.

Uni-axial stress is the simplest type. Biaxial stresses are the plane stress acting in directions at right angles. Biaxial stress conditions are, from the view point of engineering application, more important than that of triaxial stress. Consequently, biaxial stresses were chosen in this series of study.

The first biaxial stress expeiments ${ }^{19}$ in this series of tests were made on flat, cross-shaped specimens which were subjected to cross bending to produce two compressions or two tensions at right angles to each other. The stress distribution was so irregular that no safe comparisons could be made. Since difficulties were encountered, this form of test specimen was discarded and after a preliminary test, hollow cylinders were adopted.

The parameter in this experiment is three kinds changes in concrete strength and changes in stress ratios. 140 specimens were tested in all : 44 specimens were subjected to compression and internal water pressure, and the remaining 96 specimens to compression and torsion. Test was also carried out in each case for pure compression, pure tension, and pure torsion, and at the same time, test of combined axial tension and internal water pressure was made as a preliminary test. The outline of the test program was as shown on tables

Table 1 Outline of Test Program, I) Compression-Tension

\begin{tabular}{l|r|r|r}
\hline \multirow{2}{*}{ Type of Loading } & \multicolumn{3}{|c}{ Numbers } \\
\cline { 2 - 4 } & A & B & C \\
\hline Axial Compression Only & 6 & 1 & 2 \\
Internal Water Pressure Only & 7 & 1 & 1 \\
Combinations of Internal Water & 16 & 3 & 7 \\
Pressure and Axial Compression & & 5 & 10 \\
Total (Specimens 44) & 29 & 5 &
\end{tabular}

Table 2 Outline of Test Program II) Compression-Torsion

\begin{tabular}{l|r|r}
\hline \multirow{2}{*}{ Type of Loading } & \multicolumn{2}{|c}{ Numbers } \\
\cline { 2 - 3 } & A & C \\
\hline Axial Compression only & 13 & 8 \\
Pure Torsion Only & 14 & 7 \\
Combinations of & 35 & 19 \\
Axial-Compression and Torsion & 62 & 34 \\
\hline
\end{tabular}
Nos. $1 \& 2$ as follows.
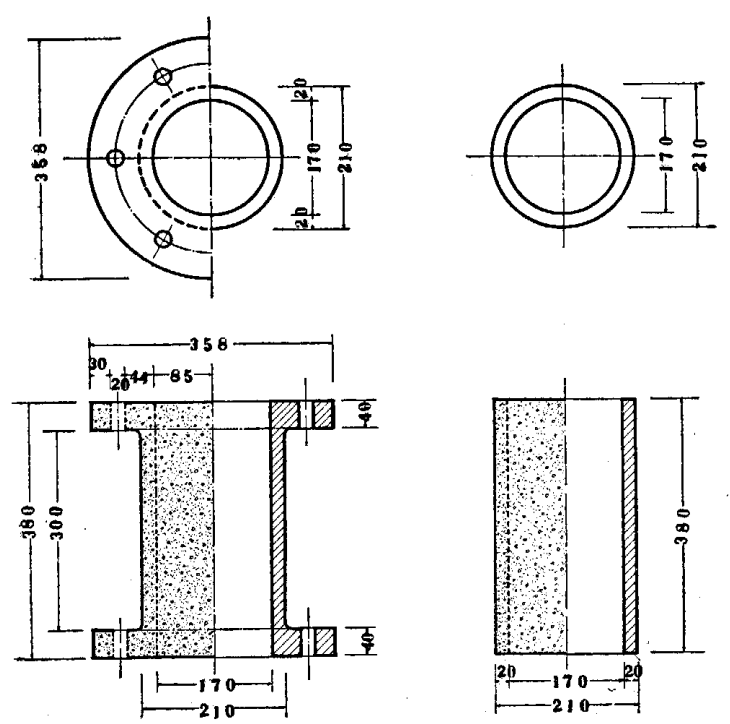

A) Compression and torsion, Tension and torsion

Fig. 1 Specimens

\section{Cross Section and Shape of Specimen}

In either case of tests Nos. $1 \& 2$, measurements of hollow concrete cylinders used for a specimens were $21 \mathrm{~cm}$ outside diameter, $17 \mathrm{~cm}$ inside diameter and $38 \mathrm{~cm}$ in height.

Speimens which were subject to compression and torsion as well as tension and internal water pressure were set up with brim-like parts at both ends to enable application of torsion and tension.

The cross section and the shape of the specimen is shown in Fig. 1 attached herewith.

\section{Making and Curing of Specimen}

Onoda's portland Cement was chosen for cement. Sand not more than $1.2 \mathrm{~mm}$ in diameter and coarse aggregate of not more than $10 \mathrm{~mm}$ in diameter were used.

In mixing, the water-cement ratio was set at $75 \%$, $65 \%$ and $55 \%$ in case 1 ), while in case 2 ) the ratio of $75 \%$ and $55 \%$ was used. Slump was approximately $21 \mathrm{~cm}$. A special type of metal form was propared. (See photo. 1)

Concrete was placed vertically only from a concrete 
mixer with a capacity of 2.5 cubic feet. After concrete placing, the specimen was covered with wet cloth and left in water to curing until the test, though the form was removed after 3 or 4 days after concrete was placed.

\section{Loading Apparatus}

The testing apparatus for compression and internal water pressure consisted of a 100 ton Amsler testing machine for applying axial compression, a rubber cylinder and a hand pump for applying internal water pressure, and the attachments of the pump. (refer to the Fig. $2 \&$ photo. 2)

The testing apparatus for compression and torsion cosisted of ;

a) 100 ton Amsler testing machine for axial compression

b) a built-up apparatus for torsional loading

口 shaped built-up frame, cross beam, oil jack, proving ring and other accessories. (refer to the Fig. 3 \& photo 3 )

Full consideration was given to axial compression force in order to eliminate eccentric loading, a special loading plate and a bearing block was used. The plate was a special loading plate arranged with the holes for water-pressure, air vents and W.S.G. wiring leads.

The torsion-loading frame assembly consisted of two end beams held together by four $13 \mathrm{~mm}$ diameter tie rods, two cross beams which transmitted the loads to torque plates connected to the ends of the specimens, an oil jack to apply the load to one of the cross beams, and a proving ring to measure the applied load. Diagonal cross beams opposite each other were loaded in such a manner that the end reactions formed opposite

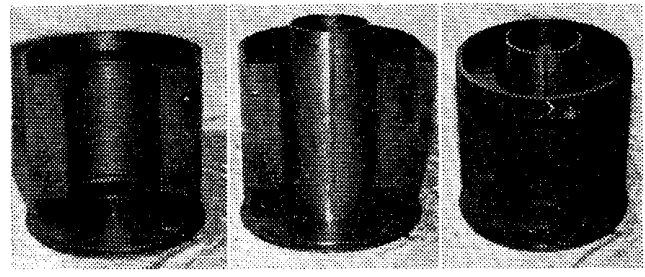

Photo-1 Metal form

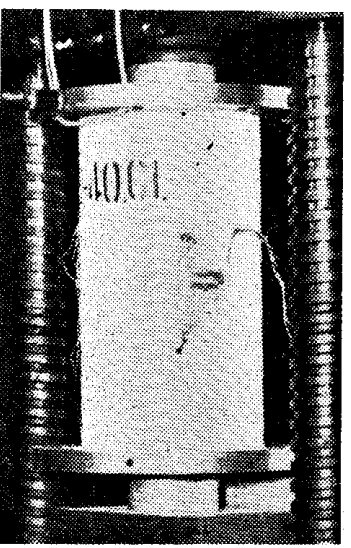

(a)

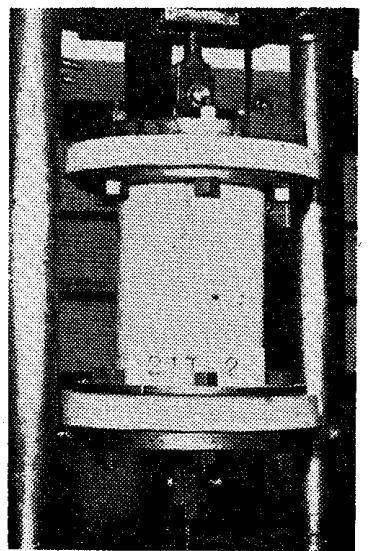

(b)

Photo-2 Testing Arrangement

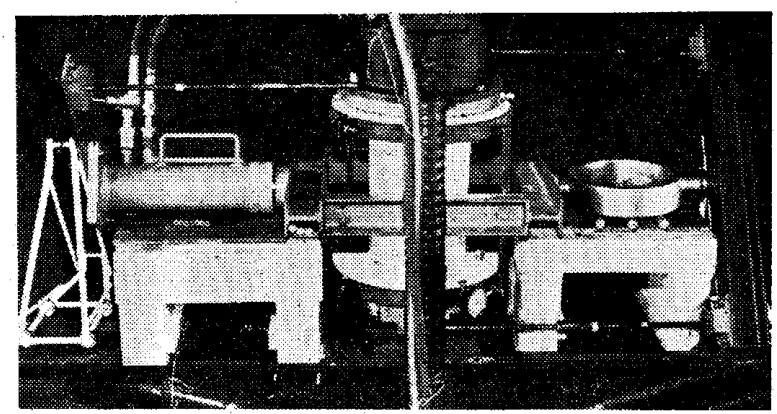

Photo-3 Testing Arrangement

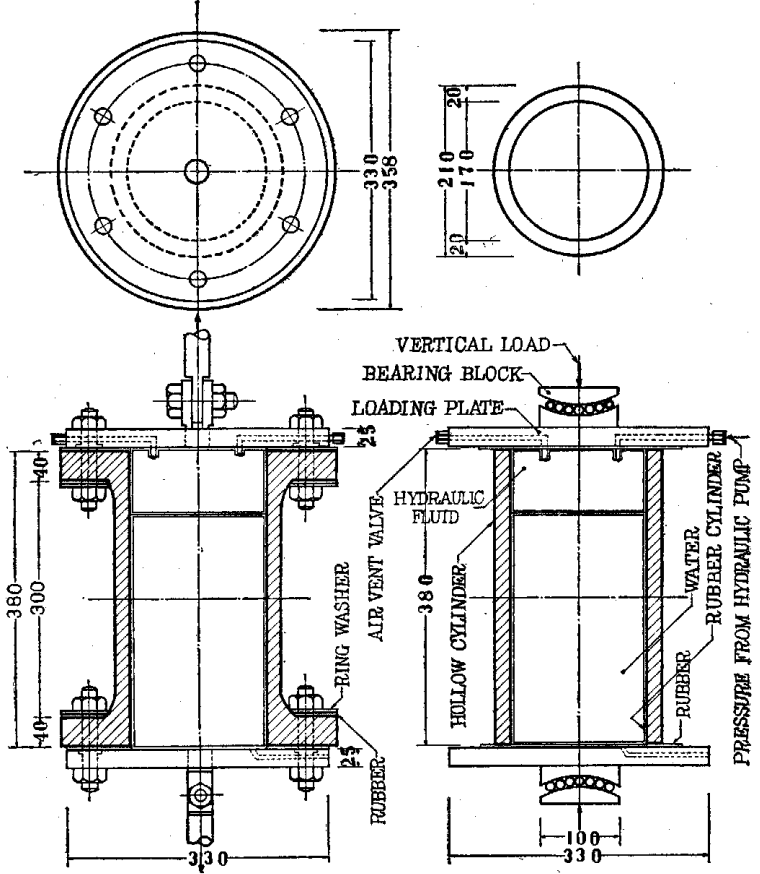

B) Axial compression and internal and internal pressure pressure

Fig. 2 Method of applying internal pressure

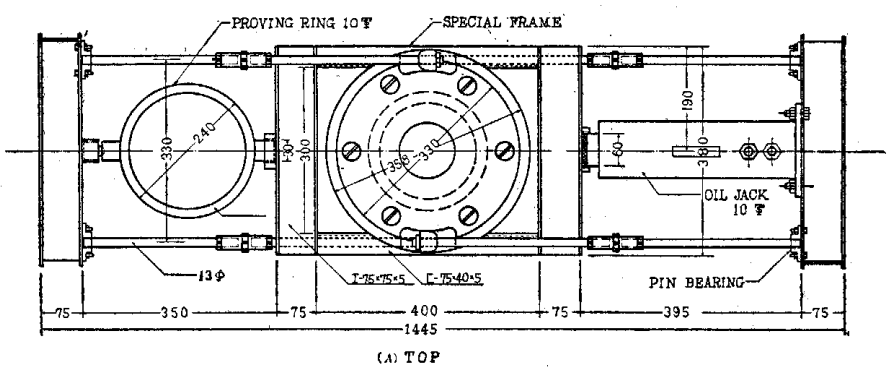

Fig. 3 (a) Method of applying the torsion and axial compression

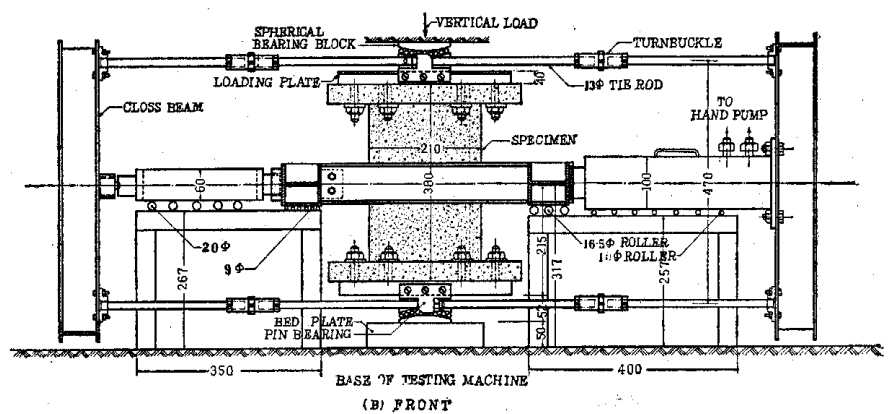

Fig. 3 (b) 
couples at each end of the specimen. The each end of the bar was pinjointed so that we could avoid possible torsion arising from delicate revolving movement of the specimen between the frame.

In case of axial tension, the experiment was performed by attaching a special tension apparatus to the loading plate. (See the Fig. 1)

\section{Test procedure}

Specimens were originally planned to be tested under the age of 28 days. However, their age was extended one week or so because of some impediments encountered in the course of the experiment. Both ends of the specimen were sand polished to smooth surfaces to attain uniform stress distribution.

\section{A) Axial Compression :}
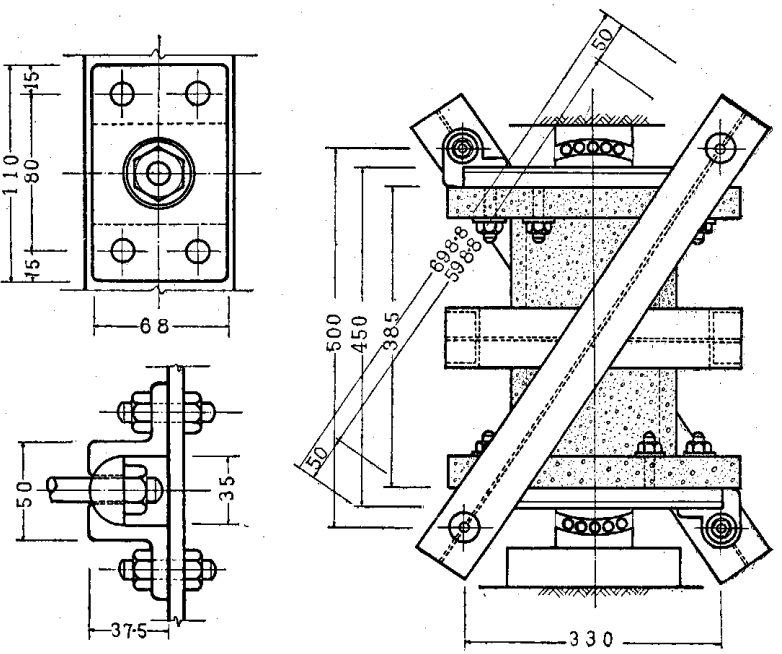

(D) PIN BEARING

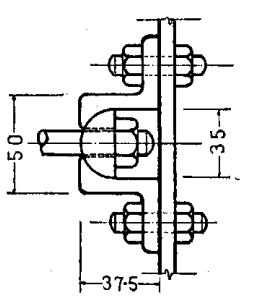

Fig. 3 (c)

Brimless hollow concrete cylinders were tested in a 100ton Amsler testing machine at a loading rate of approx. $5 \mathrm{~kg} / \mathrm{min}$. To attain uniform stress distribution, rubber packing was used between the loading plate and the special specimen. The load was applied intermittenly in order to measure strain distribution by the W.S.G.

B) Internal Water Pressure :

Specimens were installed on a loading plate. The first rubber cylinder filled with water was put into the specimen and then the second rubber cylinder was inserted over the first rubber cylinder, while it was kept fixed on the loading plate. Water pressure was applied to the rubber cylinder through the upper part of the loading plate with the hand pump. (refer to the Fig. 2)

C) Combination of Compression and Internal Water Pressure :

Two different loading methods were adopted :

a) Axial compression was applied first, and then internal water pressure was gradually increased until failure.

b) The reverse of a)

D) Pure Torsion

The torsional loading apparatus was supported on two wooden supports on a 100 ton Amsler testing machine. A shaped frame, oil jack, proving ring, cross beam were installed on a straight line and supported with rollers. Load was gradually increased with a hand pump and was read by a dial gage in the proving ring.

E) Combination of Axial Compression and Torsion :

Two methods of loading were adopted:

a) Specific amount of axial compression load was given, and then torsional load applied thereto until failure.

b) Reverse of a)

F) Combination of Axial Tension and Internal Water Pressure

After the apparatus applying axial tension to the loading plate was installed, the brim-like part of the specimen was anchored on the loading plate with bolts. The apparatus for internal water pressure was put into the specimen before the loading plate was connected to the specimen. A specified amount of axial tension was applied first and then the internal water pressure was gradually increased until failure.

\section{Results of Experiments}

\subsection{Relationship between stress-strain.}

Fig. 4 shows the relation between stress and strain when pure compression was applied to the specimens, with each curve of a uniform value in each direction, indicating that all curves are in more or less the same state of strain. Therefore, the stresses may be considered to be uniformly distributed over the cross-section of the specimens.

Fis. 5 shows the stress-strain relation when the specimens were subjected to pure internal water

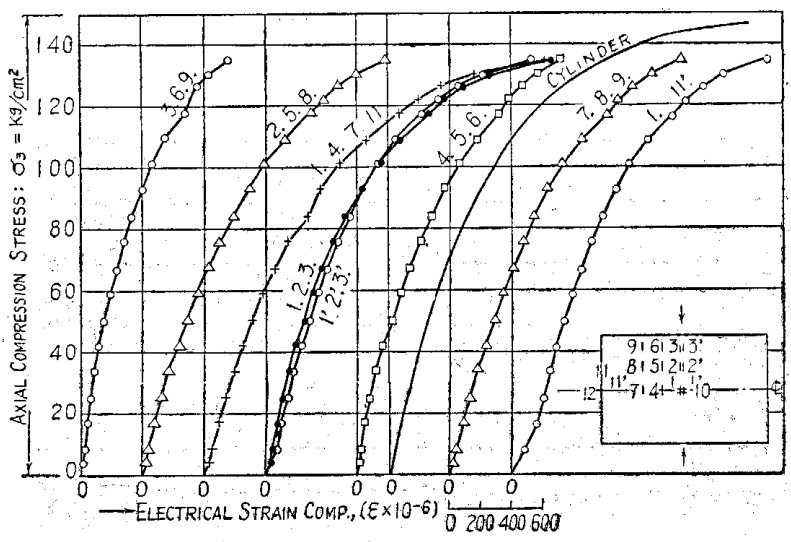

Fig. 4 Relationship of stress-strain (Pure Comp;) 
pressure. The strains on the interior and exterior surfaces of the specimens are almost identical. However, circumferential strains become a little large from the edge towards the center. This slight variation causes primary cracks, starting the failure from the center.

Fig. 6 shows the stress-strain relation when under combined stress of axial compression and internal water pressure. The variation of strain, when only axial compression is acting, indicates the same state as in Fig. 4, but with application of internal water pressure, only circumferential strains vary to a large extent, while axial strains show little or no change.

Fig. 7 shows the stress-strain relation when pure torsion is applied to the specimen. A little difference in the distribution of stress on the interior and exterior surfaces is noticed.

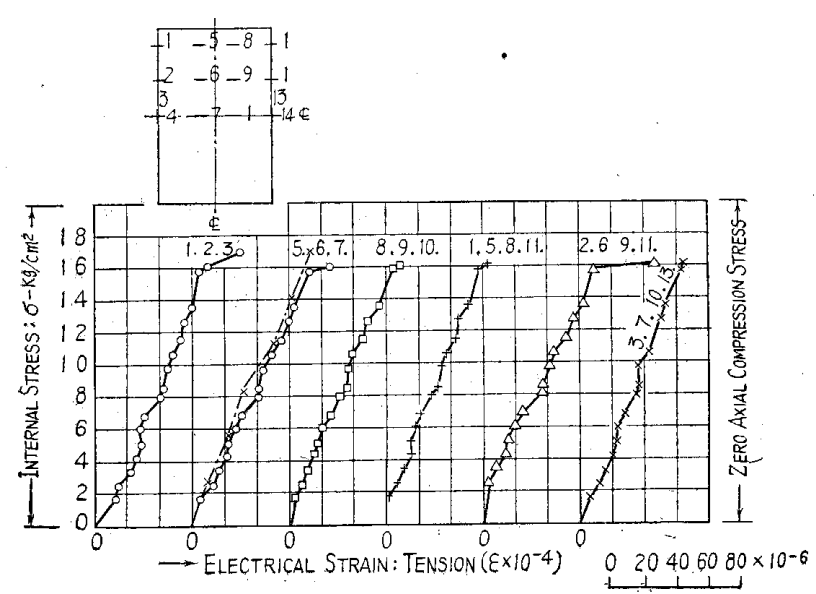

Fig. 5 Relationship of stress-strain (Pure internal pressure)

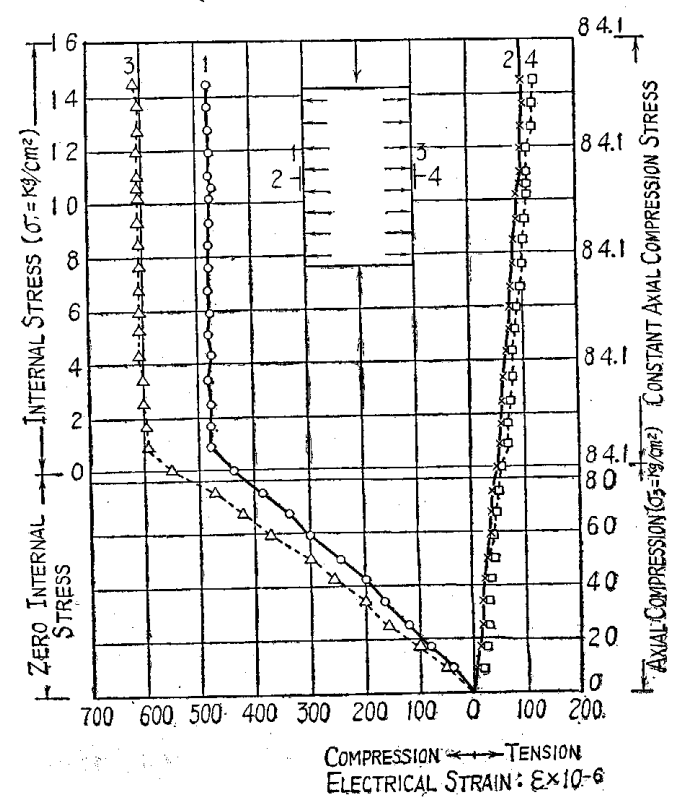

Fig. 6 Relationship of stress-strain (comp-ten)

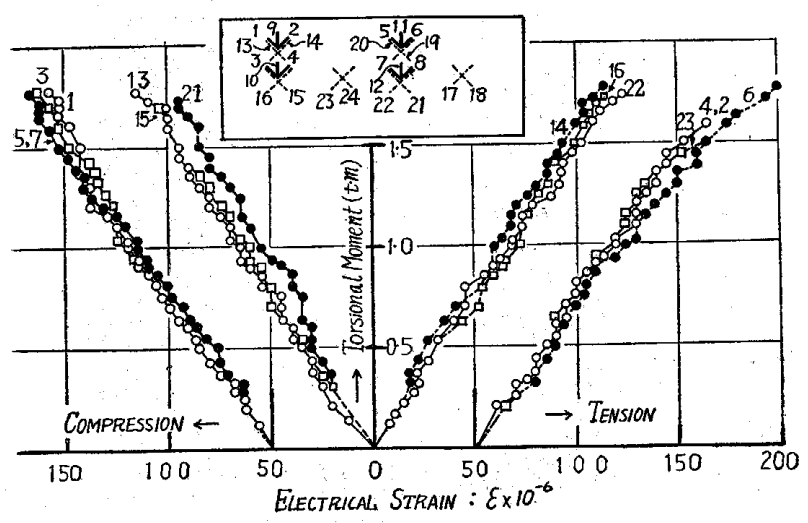

Fig. 7 Relationship of stress-strain (Pure torsion)
Fig. 8 shows the stress-strain relation when axial compression and torsion are combined. The distribution of strains clearly shows the state of combined stresses such as compressive strain by only axial compression and the variation of compressive and tensile strains after torsion began to act.

Fig. 9 shows one case of how the state of stresses influence the failure of material when axial compression and internal water pressure are combined.

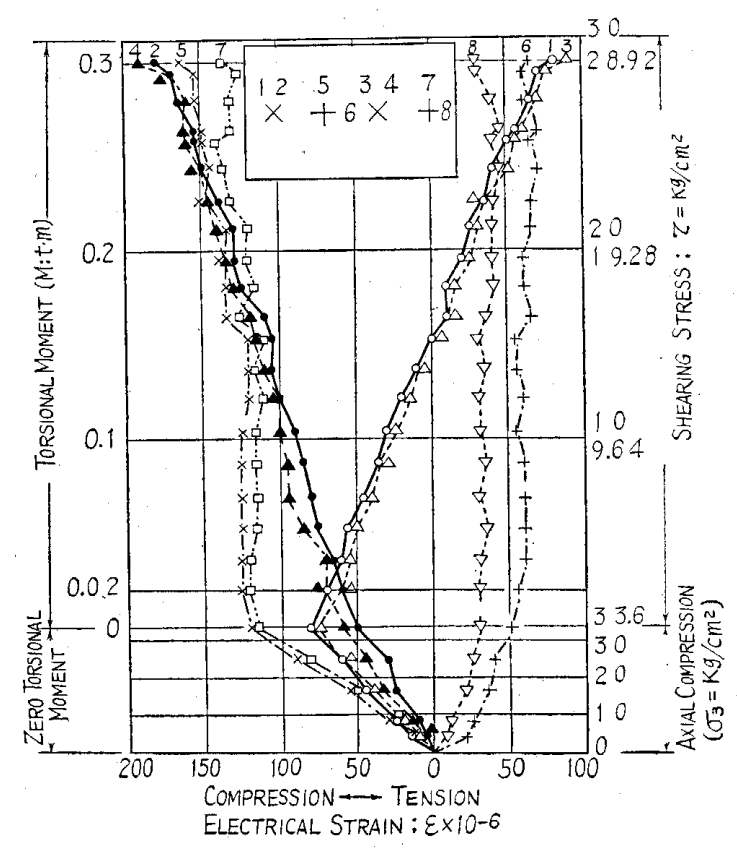

Fig. 8 Relationship of stress-strain (comp-torsion)

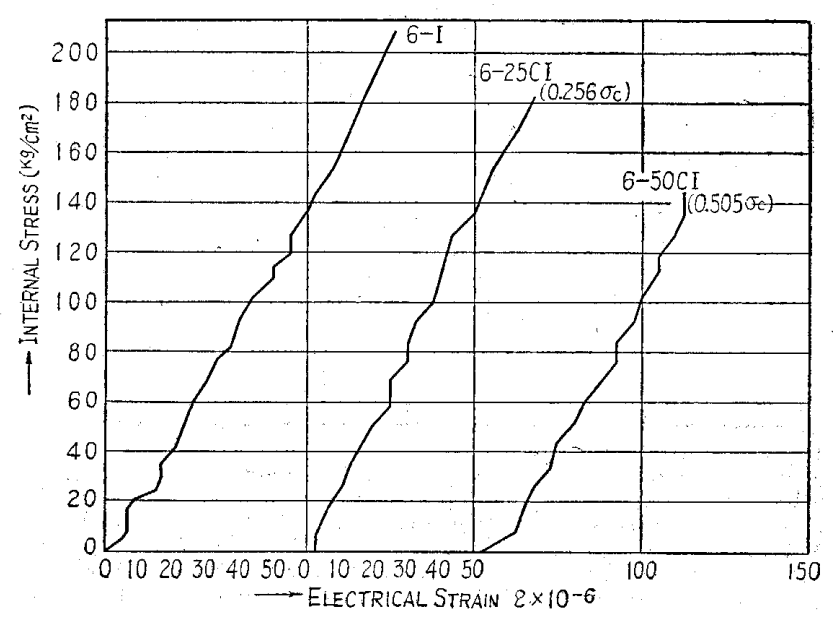

Fig. 9 Stress-strain diagrams showing general averages for series 7 (com-ten) 
As the ratio of stress varies, or in other words, the ratio of axial compression increases, there appears a phenomenon in which the breaking strength tends to lessen.

Fig. 10 is one example of a shearing stressstrain curve when axial compression and torsion are combined. In this test, very careful consideration should be given to the influence to torsional rigidity by compressive force. It is evident that the restriction of torsion by com. pressive force can be nearly ignored.

\subsection{Mode of Failure}

I) Axial Compression and Internal Water Pressure:-

As the ratio of tension to Compression is increased, the mode of failure shows a gradual transition from compressive failure (by pure compression) to tensile failure (by pure internal water pressure). (Photo 4.). The difference in loading order causes no difference in mode of failure. The dominating element is rather the ratio of tension to compression.

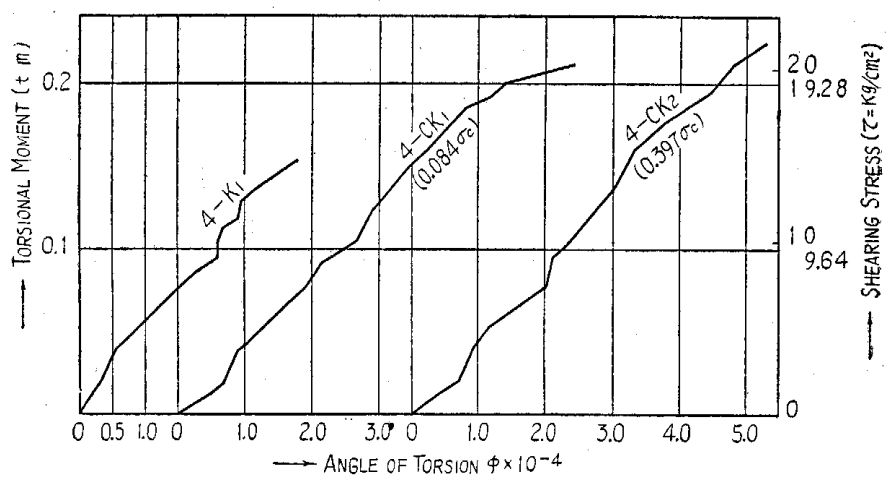

Fig. 10 Relationship between torsional moment and angle of torsion

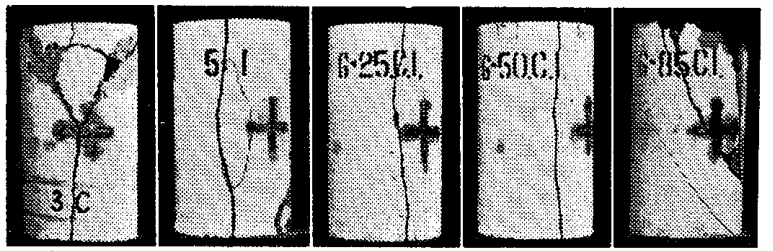

Photo-4 Mode of failures(Comp-ten ;)

II) Axial Compression and Torsion :-

Specimen subjected to pure torsion failed by helical cracks (caused by diagonal tension) at angles of little less than $45^{\circ}$ to the axis. The specimen tested next under combined stresses failed by helical cracks with the angle varying from $12^{\circ}$ to $35^{\circ}$ according to the amount of axial compression. The inclination of the cracks vary with the relative magnitude of axial compression load, but it can be ascertained that there is no correlation at all between the inclination angle of cracks and loading conditions or the nominal compressive strength of concrete (Fig. 11 and Photo 5).

III) Axial Tension and Internal Water Pressure:-

A pure axial tension test was performed as a preliminary test. The mode of failure is shown in Photo 6.

\subsection{Results of Experiments}

Stresses at failure were calculated from the load measured and shown in Table 3.

I). Axial Compression and Internal Water Pressure:-

Fig. 12 and Fig. 13 show the biaxial relation of combined stresses at failure of axial compression and internal water pressure. It does not seem from these data that the condition of failure by the combination of tension and compression is formularized in a simple straight line or curve relation between principal
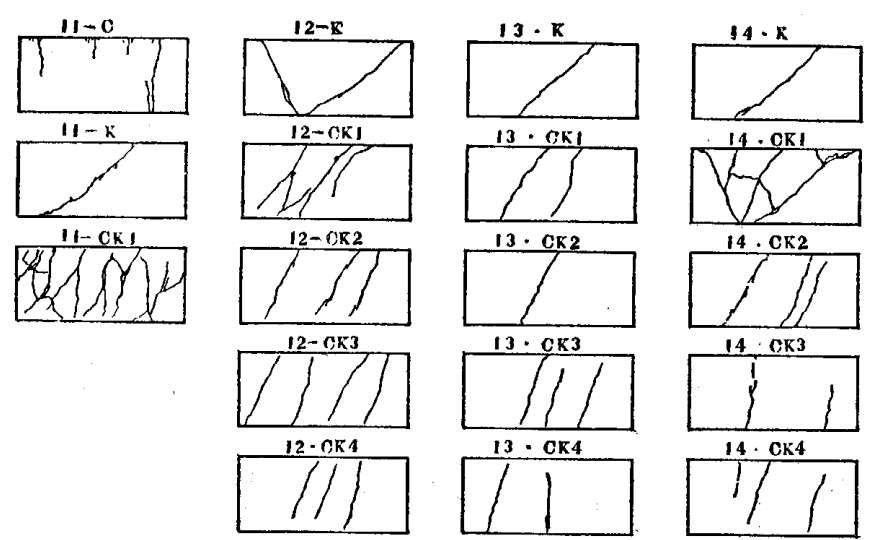

Fig. 11 Mode of failure (Extend elevation)

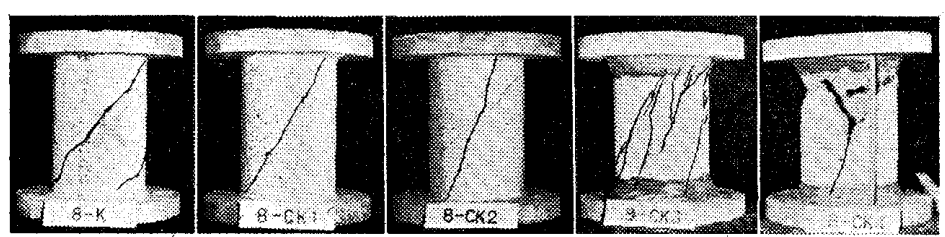

Photo-5 Mode of failure (Comp-torsion) stresses. It also seems difficult to apply the Mohr's theory on failure which has been employed to explain the state of compression with two or three axes (Fig. 12 and Fig. 13)

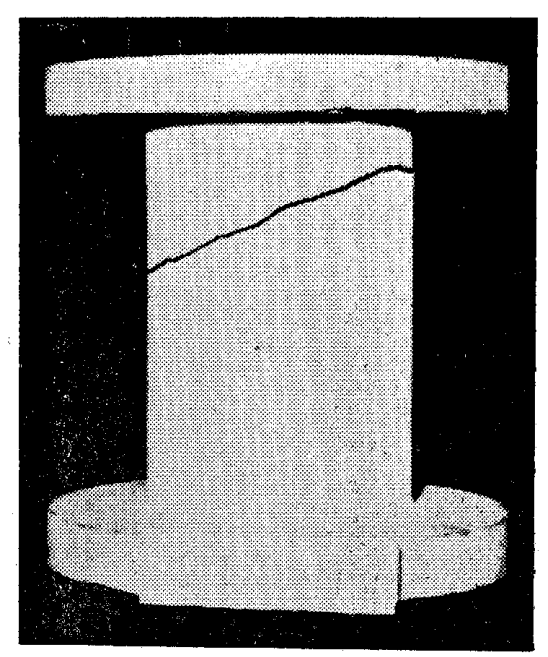

Photo-6 Mode of failure (ten-ten) 
II) Axial Compression and Torsion :-

Principal stresses at failure $\left(\sigma_{1}\right.$ and $\left.\sigma_{2}\right)$ and their ratio $\left(\sigma_{1} / \sigma_{c}\right),\left(\sigma_{2} / \sigma_{c}\right)$ were computed for each specimen and their relations are shown in Fig. 14 and Fig. 15. These data show, except for two or three exceptions, types of failure which do not correspond with either the maximum stress theory or Coulomb's internal friction theory.

\section{Observation on Results of Experi- ments}

The experiment results of combined stresses in I) and II) of 9. 3) cannot be explained by the various existing theories on failure, nor even by the maximum principal stress theory which states that failure has no relation to the existence of middle and minimum principal stresses. As seen from the mode of failure, the surface of failure seems to appear at the surface where shearing force exists. This calls to mind Mohr's theory. Mohr's theory, however, ignores middle principal stresses, while past experiments by others proved that the existence of middle principal stresses have large influence to failure. In fact, as seen from the results of our experiments, Mohr's theory can not be applied in this case.

Attempts have been made to analyze this problem by applying A. Nadai's theor ${ }^{20)}$ on failure, that octahedral shearing stress are functions of octahedral normal stresses.

\subsection{Octahedral Stress}

The following standard defines the theory of failure by octahedral stress in that failure starts when shearing stresses on the surfaces of a octahedron reaches certain values.

$$
\tau_{0}=F\left(\sigma_{0}\right)
$$

$\sigma_{0}$ and $\tau_{0}$ represent normal and shearing

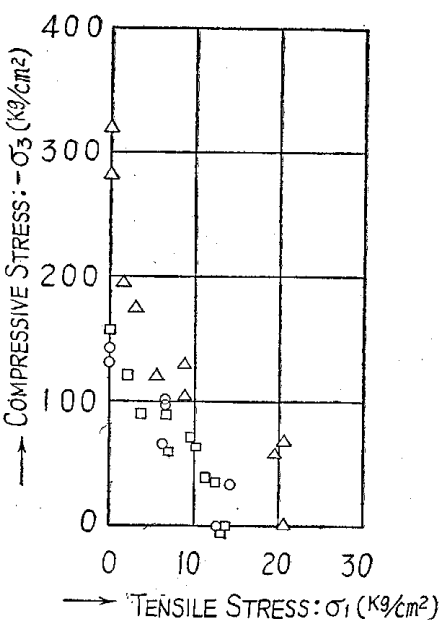

Fig. 12 Relationships between principal stress at failure (Comp-tens)

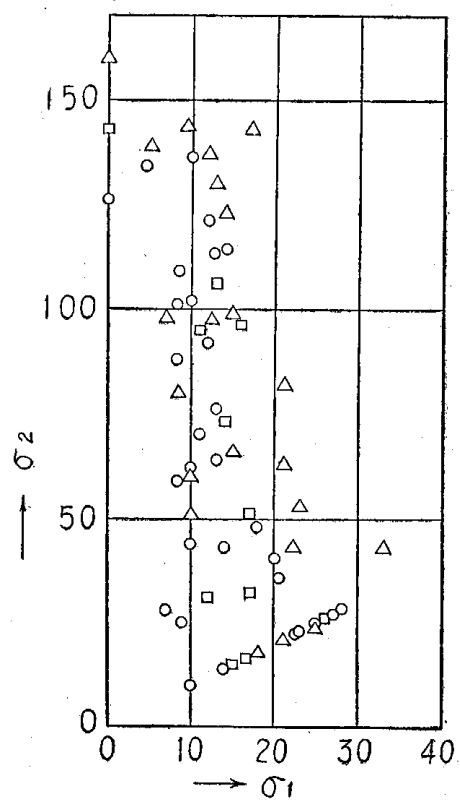

Fig. 14 Relationships between principal stress at failure (Comp-torsion)

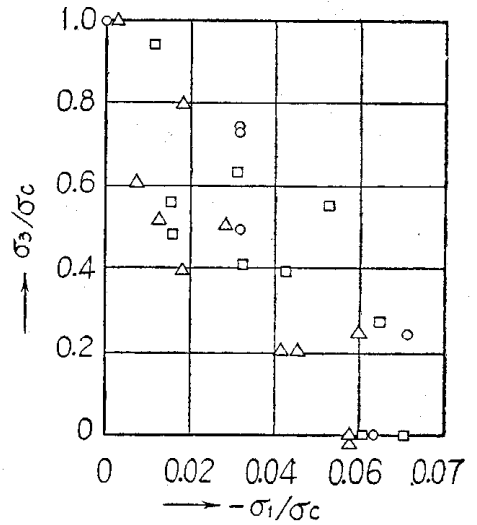

Fig. 13 Relationships dimensionless between principal stress at failure

(Comp-tens)

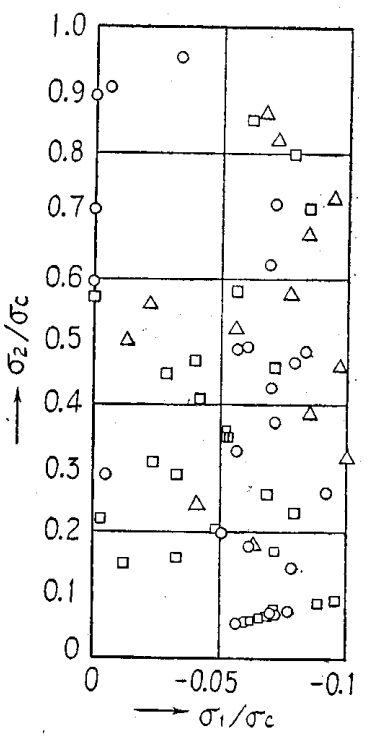

Fig. 15 Relationships dimensionless between principal at failure (Comp-torsion)

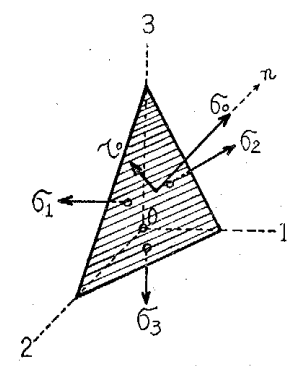

Fig. 16

Octahedral plane stresses on a octahedral plane. Octahedral stresses arise on the sides of a octahedron forming equal angles to the axes of principal stresses (Fig. 16) and is represented by the following equation (10.1.2)

$$
\left.\begin{array}{l}
\sigma_{0}=\frac{1}{3}\left(\sigma_{1}+\sigma_{2}+\sigma_{3}\right) \\
\tau_{0}=\frac{1}{3} \sqrt{\left(\sigma_{1}-\sigma_{2}\right)^{2}+\left(\sigma_{2}-\sigma_{3}\right)^{2}+\left(\sigma_{3}-\sigma_{1}\right)^{2}}
\end{array}\right\}
$$

In the plastic theory, octahedral shearing stress becomes the basic element to determine the character of the development of plastic deformation. Dr. R. Hill ${ }^{21}$ and Dr. Jr. Hodge ${ }^{22}$ apply the conception of yield conditions of plastic material to the development of yield standards, giving octahedral stress expressions different from that mentioned above. Assuming that material possess isotropy and that yield condition depends only on the magnitude of the three principal stresses without relation to the direction of these stresses, the yield condition takes a form of

$$
F\left(J_{1}, J_{2}, J_{3}\right)=0
$$

$J_{1}, J_{2}$, and $J_{3}$ shown here represent the first three invariants with low degree of stress tensor $\sigma_{i j}$. They will be also expressed as follows by applying principal stresses $\sigma_{1}, \sigma_{2}$ and $\sigma_{3}$. 


$$
\begin{aligned}
& J_{1}=\sigma_{1}+\sigma_{2}+\sigma_{3} \\
& J_{2}=\left(\sigma_{1} \sigma_{2}+\sigma_{2} \sigma_{3}+\sigma_{3} \sigma_{1}\right), \quad J_{3}=\sigma_{1} \sigma_{2} \sigma_{3}
\end{aligned}
$$

From these formulas, octahedral stress is expressed as follows.

$$
\begin{aligned}
& \sigma_{0}=\frac{1}{3} J_{1} \\
& \tau_{0}=\frac{1}{3}\left[2\left(J_{1}^{2}-3 J_{2}\right)\right]^{1 / 2}
\end{aligned}
$$

Accordingly, the failure standard of the equation (10.1.1) becomes $F\left(J_{1}, J_{2}\right)=0$

\subsection{Observation by Octahedral Stress}

I) Axial Compression and Internal Water Pressure :-

The computation of octahedral stress from experimental values shows the results listed in Table 3. and Fig. 17. Fig. 17 is a dimensionless plot of the equations (10.1.3) and (10.1.5). Each of these experimental values are consolidated by the method of leasts square and represented by the following formula.

$$
-\frac{\tau_{0}}{f_{c}}=1.17 \frac{\sigma_{0}}{f_{c}}+0.067
$$

It becomes clear that the relation between $\sigma_{0}$ and $\tau_{0}$ corresponds quite well with the experiment by axial compression and torsion explained hereinafter.

II) Axial Compression and Torsion :-

Experimental values are analyzed in the same manner as in $I$ ) and their results are shown in Table 3 and Fig. 18, 19 and 20. The following formulas indicate the correlation between normal stress and shearing stress based on stress at failure (Fig. 18, 19 and 20).

$$
\begin{aligned}
-\frac{\tau_{0}}{f_{c}} & =1.12 \frac{\sigma_{0}}{f_{c}}+0.07 \cdots \cdots(10.2 .2) \\
\text { or }-\frac{\tau_{0}}{f_{c}} & =1.14 \frac{\sigma_{0}}{f_{c}}+0.072 \cdots \cdots(10.2 .3) \\
-\frac{\tau_{0}}{\sigma_{c}} & =1.12 \frac{\sigma_{0}}{\sigma_{c}}+0.092 \cdots \cdots(10.2 .4)
\end{aligned}
$$

Formula (10.2.2) of the above formulas re-

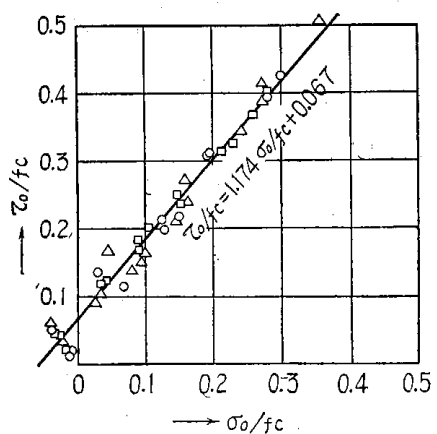

Fig. 17 Relationship between octahedral plane stress $a^{t}$ failure (Comp-tension)

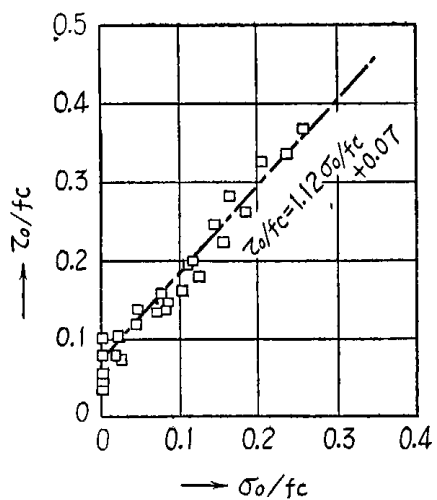

Fig. 19 Relationship between octahedral plane stress at failure

concrete strength $f_{c}=200 \sim 300 \mathrm{~kg} / \mathrm{cm}^{2}$

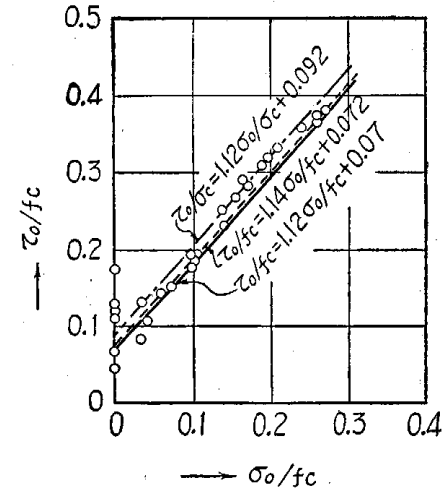

Fig. 18 Relationship between octahedral plane stress at failure (Comp-torsion) Concrete strength $f_{c}=100 \sim 200 \mathrm{~kg} / \mathrm{cm}^{2}$

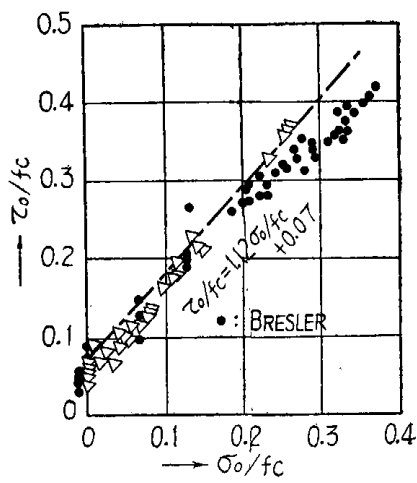

Fig. 20 Relationship between octahedral plane stress at failure (Comp-torsion) concrete strength $f_{c}>300 \mathrm{~kg} / \mathrm{cm}^{2}$

presents the straight line relation of all the specimens by the method of leasts square, and formula (10.2.3) shows the straight line relation within the limit of concrete strength $f_{c}=100 \sim 200 \mathrm{~kg} / \mathrm{cm}^{2}$. Formula (10.2.4) is derived by replacing cylinder strength $f_{c}$ with the hollow cylinder strength $\sigma_{c}$.

In general, experimental data can be consolidated by a curve of a simple equation, but it seems that the stronger the concrete strength is, experimental values go farther below the respective curve. This is considered to be due to the decrease in the ratio of tensile strength to compressive strength of concrete $\left(\sigma_{t} / \sigma_{c}\right)$ with the increase of the compressive strength of concrete.

The generally approved relation between shearing stress and normal stress is expressed as follows by the formula $(10.2 .2)$ and the formula of octahedral stress (10.1.5)

$$
\frac{\tau}{f_{c}}=\sqrt{-0.124\left(\frac{\sigma}{f_{c}}\right)^{2}+0.078\left(\frac{\sigma}{f_{c}}\right)+0.0074}
$$

Fig. 21 shows the relation between experimental values and the experimental formula of shearing stress $\tau$ and normal stress $\sigma$. As the compressive strength of a hollow cylinder $\sigma_{c}$ becomes $78.5 \%$ of the standard cylinder strength, the formula (10.2.5) is revised as follows.

$$
\frac{\tau}{\sigma_{c}}=\sqrt{-0.104\left(\frac{\sigma}{\sigma_{c}}\right)^{2}+0.095\left(\frac{\sigma}{\sigma_{c}}\right)+0.0089}
$$

Accordingly, when calculated from the straight line standard, the maximum shearing strength at com- 
pressive stress $\sigma$ is $\tau=0.17 \sigma_{c}\left(\sigma=0.45 \sigma_{c}\right)$ and the pure shearing strength is $\tau=0.09 f_{c}$.

The equation (10.2.2) is the result of experiments in the case of biaxial stresses, and a comparative study of the results by use of the experimental results of the state of combined stresses of more than three axes is shown in Fig. 22. The data used for comparison purposes include those of Messrs. Ito $^{2)}$, Wollak, Balmer, Richart, and Freudenthal. As these data have been obtained from different method of loading, strength and shape of specimens and show standards of failure of individual peculiarities, it is impossible to make a comparison which considers all kinds of influences.

As is clear from the diagram, the experiment of biaxial stresses can be fully expressed by a simple equation relation, while the test results of triaxial stresses deviate to a certain extent from the curve of a simple equation. This non-coincidence with the primary relation is considered to be due to the influence of the third invariant. The third invariant is $J_{3}=0$ in case of biaxial stresses and $J_{3} \neq 0$ in case of triaxial stresses. This was also pointed out by Dr. B. Bresler $^{12}$ who proved the appropriateness of the general formula for standard of failure $F\left(J_{1}, J_{2}, J_{3}\right)$

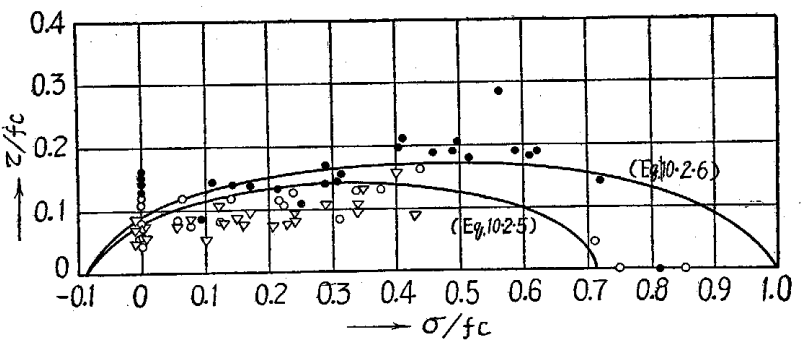

Fig. 21 Shear-compression strength

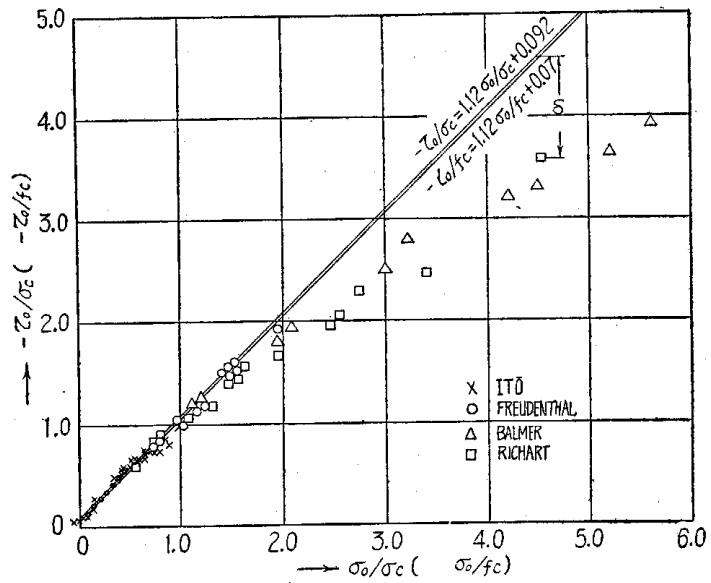

Fig. 22 Comparison octahedral plane stress

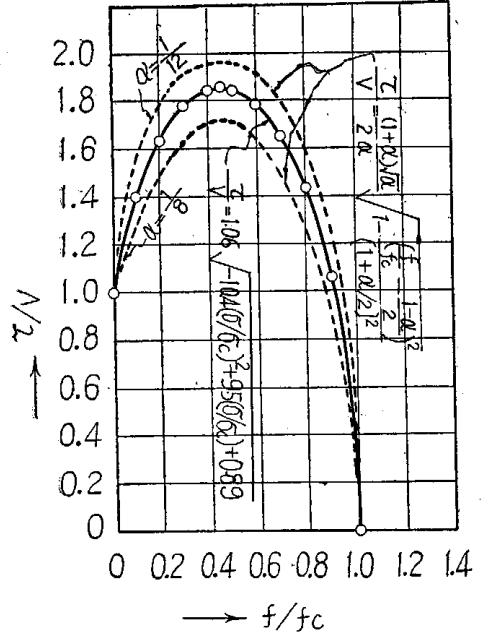

Fig. 23 Relationship between $\tau / V$ and $f / f_{c}$
$=0$ considering the third invaliant $J_{3}$ (Fig. 22).

The correlation between shearing stress-shearing force and compressivestress-compressive force is represented by the following formula based on the formula (10.2.6), assuming that pure shearing force is $V=0.0945 \sigma_{c}$.

$$
\frac{\tau}{V}=1.06 \sqrt{-10.4\left(\frac{\sigma}{\sigma_{c}}\right)^{2}+9.5\left(\frac{\sigma}{\sigma_{c}}\right)+0.89}
$$

The curve drawn by this equation is shown in Fig. 23. In connection with this, there is a envelop equation by Dr. S.A. Guralnick based on the pure shearing circle and a pure compressive circle introduced by Mohr as an approximate line of the limit of failure by Mohr. The equation is expressed as a function of tensile strength and compressive strength of concrete and the formula $(10.2 .7)$ has shown fairly good coincidence with $\alpha=f_{t} \mid f_{c}=1 / 10$.

\section{Conclusion}

1) Axial Compression and Internal Pressure:- The strength of the hollow cylinder under pure compression was smaller than expected, indicating the decrease of the compressive strength of the hollow cylinder to

78.5\% of cylinder strength. This decrease of the hollow cylinder strength under pure compression is considered to be due to the influence of the expansion of the hollow cylinder by the modulus of Poisson. This expansion causes an earlier failure of the hollow cylinder as compared with the case of ordinary cylinders due to the restriction conditions at both ends of the cylinder.

Roughly assuming that a stress is $50 \%$ of the ultimate strength in case the stress acts purely, the other resisting stress decreases to a range of about 40 to $60 \%$.

However, the relation of failure between principal stresses is not clearly established, and it follows that it is difficult to decide whether its relation will draw a curve or a straight line in the diagram. As regards to the relation of principal stresses at failure, Mohr's theory cannot be applied within the range of tension and compression, as it is proved that middle principal stress $\sigma_{2}$ has a large influence to the condition of failure. A straight line relation noticed in the relation of octahedral stress at failure almost corresponds with the case of compression and torsion. However, the generalization of the condition of failure regarding the state of the combined stresses of compression and tension will require more experimental results for some time to come.

II) Axial Compression and Torsion:-

Satisfactory results were obtained regarding the relation between stress and strain in the state of com- 
bined stresses. As regards the relation between principal stresses at failure $\left(\sigma_{1}, \sigma_{2}\right)$ and $\left(\sigma_{1} / \sigma_{c}, \sigma_{2} / \sigma_{c}\right)$, these experimental data clearly show with two or three exceptions that there are types which do not correspond with either of the maximum stress theory or Coulomb's internal friction theory.

The correlation of octahedral stresses at failure can be approximately represented by an straight line, but shows a scattered distribution of the data to some extent depending on concrete strength. The relation between shearing force and normal force is represented by the formula (10.2.6), but experimental values fall inside the curve in case $\sigma / f_{c}$ is below 0.3 and outside the curve within the range of $\sigma / f_{c}=0.3 \sim 0.7$. In general, however, such a straight line standard as shown by the formula (10.2.6) is most desirable.

The theories stated above apply to biaxial states of various stresses ranging from pure compression to pure shearing, but not to triaxial state of those stresses.

Table 3 (a) Convention Compressive and Tensile Stresses at Failure

\begin{tabular}{|c|c|c|c|c|c|c|c|c|c|c|c|c|}
\hline \multirow{2}{*}{$\begin{array}{l}\text { Specimens } \\
\text { No. }\end{array}$} & \multirow{2}{*}{$-f_{c}$} & \multicolumn{2}{|c|}{ Actual Stresses } & \multicolumn{2}{|c|}{ Adjusted Stresses } & \multirow{2}{*}{$\begin{array}{c}\text { Percent of } \\
\text { Tensil } \\
\text { Strength }\end{array}$} & \multirow{2}{*}{$\sigma_{3} / \sigma_{C}$} & \multirow{2}{*}{$-\sigma_{1} / \sigma_{c}$} & \multirow[b]{2}{*}{$-\sigma_{0}$} & \multirow[b]{2}{*}{$\tau_{0}$} & \multirow[b]{2}{*}{$-\sigma_{0} / f_{c}$} & \multirow[b]{2}{*}{$\tau_{0} / f_{c}$} \\
\hline & & $-\sigma_{c}$ & $\sigma_{1}$ & $-\sigma_{3}$ & $\sigma_{1}$ & & & & & & & \\
\hline $\begin{array}{l}1-\mathrm{C} \\
1-\mathrm{I} \\
1-25 \mathrm{CI} \\
1-50 \mathrm{CI} \\
1-75 \mathrm{CI}\end{array}$ & 159 & $\begin{array}{r}134.0 \\
17.0 \\
33.6 \\
67.1 \\
100.1\end{array}$ & $\begin{array}{r}17.00 \\
19.10 \\
8.50 \\
8.50\end{array}$ & $\begin{array}{c}134.0 \\
0 \\
33.6 \\
67.1 \\
100.7\end{array}$ & $\begin{array}{r}0 \\
17.00 \\
19.10 \\
8.50 \\
8.50\end{array}$ & $\begin{array}{r}0 \\
100.0 \\
112.4 \\
50.0 \\
50.0\end{array}$ & $\begin{array}{l}1.000 \\
0 \\
0.251 \\
0.500 \\
0.750\end{array}$ & $\begin{array}{l}0 \\
0.127 \\
0.143 \\
0.063 \\
0.063\end{array}$ & $\begin{array}{r}44.7 \\
-5.7 \\
4.8 \\
19.6 \\
30.7\end{array}$ & $\begin{array}{r}63.3 \\
8.0 \\
21.8 \\
33.9 \\
49.5\end{array}$ & $\begin{array}{r}0.281 \\
-0.036 \\
0.302 \\
0.133 \\
0.193\end{array}$ & $\begin{array}{l}0.398 \\
0.051 \\
0.137 \\
0.213 \\
0.311\end{array}$ \\
\hline $\begin{array}{l}2-\mathrm{C} \\
2-\mathrm{I} \\
2-25 \text { IC } \\
2-50 \text { IC } \\
2-83 \text { IC }\end{array}$ & 151 & $\begin{array}{r}127.5 \\
62.0 \\
94.4\end{array}$ & $\begin{array}{r}16.10 \\
4.04 \\
8.06\end{array}$ & $\begin{array}{c}134.0 \\
0 \\
65.4 \\
99.5\end{array}$ & $\begin{array}{r}0 \\
17.00 \\
4.26 \\
8.50\end{array}$ & $\begin{array}{r}0 \\
100.0 \\
25.1 \\
50.0\end{array}$ & $\begin{array}{l}1.000 \\
0 \\
0.488 \\
0.741\end{array}$ & $\begin{array}{l}0 \\
0.127 \\
0.031 \\
0.063\end{array}$ & $\begin{array}{r}42.5 \\
-5.4 \\
19.3 \\
29.1\end{array}$ & $\begin{array}{r}60.0 \\
7.6 \\
30.2 \\
46.6\end{array}$ & $\begin{array}{r}0.282 \\
-0.036 \\
0.123 \\
0.193\end{array}$ & $\begin{array}{l}0.398 \\
0.050 \\
0.200 \\
0.309\end{array}$ \\
\hline $\begin{array}{l}3-C \\
3-I \\
3-25 \mathrm{CI} \\
3-50 \mathrm{CI} \\
3-\mathrm{I}\end{array}$ & 143 & $\begin{array}{r}129.0 \\
32.7 \\
65.5\end{array}$ & $\begin{array}{l}4.72 \\
3.31 \\
0.945 \\
5.67\end{array}$ & $\begin{array}{c}143.5 \\
0 \\
36.4 \\
72.8\end{array}$ & $\begin{array}{l}0 \\
5.27 \\
3.70 \\
1.06 \\
6.33\end{array}$ & $\begin{array}{r}0 \\
100.0 \\
70.2 \\
20.1 \\
120.1\end{array}$ & $\begin{array}{l}1.000 \\
0 \\
0.254 \\
0.507\end{array}$ & $\begin{array}{l}0 \\
0.037 \\
0.026 \\
0.007 \\
0.044\end{array}$ & $\begin{array}{r}43.0 \\
-1.6 \\
9.8 \\
21.5 \\
-1.6 \\
\end{array}$ & $\begin{array}{r}60.8 \\
2.2 \\
16.7 \\
31.1 \\
2.7\end{array}$ & $\begin{array}{r}0.301 \\
-0.011 \\
0.068 \\
0.150 \\
0.011\end{array}$ & $\begin{array}{l}0.425 \\
0.015 \\
0.117 \\
0.218 \\
0.099\end{array}$ \\
\hline $\begin{array}{l}4-C \\
4-I \\
4-50 \mathrm{CI} \\
4-30 \mathrm{CI} \\
4-70 \mathrm{CI}\end{array}$ & 183 & $\begin{array}{r}155.0 \\
63.0 \\
37.8 \\
88.3\end{array}$ & $\begin{array}{r}8.50 \\
13.20 \\
14.90 \\
46.80\end{array}$ & $\begin{array}{c}155.0 \\
0 \\
63.0 \\
37.8 \\
88.3\end{array}$ & $\begin{array}{c}0 \\
8.50 \\
13.20 \\
14.90 \\
4.70\end{array}$ & $\begin{array}{r}0 \\
100.0 \\
155.3 \\
175.3 \\
55.3\end{array}$ & $\begin{array}{l}1.000 \\
0 \\
0.406 \\
0.244 \\
0.570\end{array}$ & $\begin{array}{l}0 \\
0.055 \\
0.085 \\
0.096 \\
0.030\end{array}$ & $\begin{array}{r}51.7 \\
-2.8 \\
16.6 \\
7.6 \\
27.9\end{array}$ & $\begin{array}{r}73.1 \\
4.6 \\
33.3 \\
22.2 \\
42.9\end{array}$ & $\begin{array}{r}0.282 \\
-0.015 \\
0.091 \\
0.042 \\
0.153\end{array}$ & $\begin{array}{l}0.399 \\
0.022 \\
0.182 \\
0.121 \\
0.235\end{array}$ \\
\hline $\begin{array}{l}5-C \\
5-I \\
5-70 \mathrm{CI} \\
5-40 \mathrm{CI}\end{array}$ & 176 & $\begin{array}{r}137.0 \\
87.5 \\
56.7\end{array}$ & $\begin{array}{r}16.90 \\
8.40 \\
8.90\end{array}$ & $\begin{array}{c}142.5 \\
0 \\
91.0 \\
59.0\end{array}$ & $\begin{array}{l}0 \\
1.76 \\
8.75 \\
9.25\end{array}$ & $\begin{array}{r}0 \\
100.0 \\
49.7 \\
52.6\end{array}$ & $\begin{array}{l}1,0 \\
0 \\
0.640 \\
0.415\end{array}$ & $\begin{array}{l}0 \\
0.124 \\
0.061 \\
0.065\end{array}$ & $\begin{array}{r}45.7 \\
-5.6 \\
26.4 \\
16.0\end{array}$ & $\begin{array}{r}64.6 \\
8.0 \\
43.4 \\
29.1\end{array}$ & $\begin{array}{r}0.260 \\
-0.032 \\
0.150 \\
0.091\end{array}$ & $\begin{array}{l}0.367 \\
0.045 \\
0.247 \\
0.165\end{array}$ \\
\hline $\begin{array}{l}6-\mathrm{C} \\
6-\mathrm{I} \\
6-85 \mathrm{CI} \\
6-50 \mathrm{CI} \\
6-25 \mathrm{C}\end{array}$ & 200 & $\begin{array}{r}138.0 \\
131.0 \\
77.0 \\
38.5\end{array}$ & $\begin{array}{r}19.50 \\
3.11 \\
14.00 \\
17.90\end{array}$ & $\begin{array}{r}126.0 \\
0 \\
120.0 \\
70.5 \\
35.2\end{array}$ & $\begin{array}{r}0 \\
17.90 \\
2.85 \\
12.80 \\
16.40\end{array}$ & $\begin{array}{c}0 \\
100.0 \\
15.9 \\
71.5 \\
91.6\end{array}$ & $\begin{array}{l}1.000 \\
0.142 \\
0.922 \\
0.561 \\
0.280\end{array}$ & $\begin{array}{l}0 \\
0.142 \\
0.023 \\
0.102 \\
0.130\end{array}$ & $\begin{array}{r}46.0 \\
-6.5 \\
42.6 \\
21.0 \\
7.0\end{array}$ & $\begin{array}{r}65.1 \\
9.2 \\
62.6 \\
40.1 \\
23.6\end{array}$ & $\begin{array}{r}0.230 \\
-0.032 \\
0.213 \\
0.105 \\
0.035\end{array}$ & $\begin{array}{l}0.326 \\
0.046 \\
0.313 \\
0.200 \\
0.118\end{array}$ \\
\hline $\begin{array}{l}7-\mathrm{C} \\
7-\mathrm{I} \\
7-75 \mathrm{CI} \\
7-50 \mathrm{CI} \\
7-25 \mathrm{CI}\end{array}$ & 252 & $\begin{array}{r}269.0 \\
216.0 \\
136.0 \\
68.0\end{array}$ & $\begin{array}{l}31.10 \\
10.00 \\
15.60 \\
32.20\end{array}$ & $\begin{array}{l}416.0 \\
334.0 \\
210.0 \\
105.0\end{array}$ & $\begin{array}{l}48.20 \\
15.50 \\
24.10 \\
49.80\end{array}$ & $\begin{array}{r}0 \\
100.0 \\
32.2 \\
50.0 \\
103.3\end{array}$ & $\begin{array}{l}1.000 \\
0 \\
0.805 \\
0.505 \\
0.253\end{array}$ & $\begin{array}{l}0 \\
0.116 \\
0.037 \\
0.058 \\
0.120\end{array}$ & $\begin{array}{r}89.7 \\
-10.3 \\
68.7 \\
40.1 \\
11.9\end{array}$ & $\begin{array}{r}127.0 \\
14.7 \\
104.0 \\
68.2 \\
41.8\end{array}$ & $\begin{array}{r}0.356 \\
-0.041 \\
0.272 \\
0.159 \\
0.047\end{array}$ & $\begin{array}{l}0.505 \\
0.058 \\
0.414 \\
0.271 \\
0.166\end{array}$ \\
\hline $\begin{array}{l}8-\mathrm{C} \\
8-\mathrm{I} \\
8-75 \mathrm{CI} \\
8-50 \mathrm{CI} \\
8-25 \mathrm{CI}\end{array}$ & 390 & $\begin{array}{r}284.0 \\
175.0 \\
120.0 \\
57.5\end{array}$ & $\begin{array}{r}27.40 \\
4.03 \\
7.25 \\
26.20\end{array}$ & $\begin{array}{r}284.0 \\
0 \\
175.0 \\
120.0 \\
57.5\end{array}$ & $\begin{array}{r}0 \\
27.40 \\
4.10 \\
7.30 \\
26.20\end{array}$ & $\begin{array}{c}0 \\
100.0 \\
15.0 \\
26.2 \\
95.6\end{array}$ & $\begin{array}{l}1.000 \\
0 \\
0.616 \\
0.422 \\
0.203\end{array}$ & $\begin{array}{l}0 \\
0.097 \\
0.014 \\
0.026 \\
0.092\end{array}$ & $\begin{array}{r}94.7 \\
-9.1 \\
57.0 \\
37.6 \\
10.4\end{array}$ & $\begin{array}{r}134.0 \\
12.9 \\
83.6 \\
58.4 \\
35.0\end{array}$ & $\begin{array}{r}0.243 \\
-0.023 \\
0.146 \\
0.097 \\
0.027\end{array}$ & $\begin{array}{l}0.344 \\
0.033 \\
0.214 \\
0.150 \\
0.090\end{array}$ \\
\hline $\begin{array}{l}9-\mathrm{C} \\
9-21 \mathrm{CI} \\
9-40 \mathrm{CI} \\
9-60 \mathrm{CI} \\
9-33 \mathrm{CI}\end{array}$ & 370 & $\begin{array}{r}303.0 \\
63.9 \\
122.0 \\
185.0 \\
101.0\end{array}$ & $\begin{array}{r}25.50 \\
11.10 \\
1.70 \\
10.80\end{array}$ & $\begin{array}{r}320.0 \\
67.4 \\
128.5 \\
195.0 \\
106.4\end{array}$ & $\begin{array}{r}26.90 \\
11.70 \\
1.79 \\
11.40\end{array}$ & 0 & $\begin{array}{l}1.000 \\
0.210 \\
0.400 \\
0.610 \\
0.333\end{array}$ & $\begin{array}{l}0 \\
0.084 \\
0.037 \\
0.006 \\
0.036\end{array}$ & $\begin{array}{r}101.0 \\
12.8 \\
37.0 \\
60.1 \\
30.1\end{array}$ & $\begin{array}{r}143.1 \\
37.7 \\
60.4 \\
87.6 \\
50.4\end{array}$ & $\begin{array}{l}0.273 \\
0.034 \\
0.100 \\
0.162 \\
0.081\end{array}$ & $\begin{array}{l}0.386 \\
0.102 \\
0.163 \\
0.237 \\
0.136\end{array}$ \\
\hline
\end{tabular}

Table 3 (b) Convention Compressive and Tovsional Stresses at Failure

\begin{tabular}{|c|c|c|c|c|c|c|c|c|c|c|}
\hline \multirow{2}{*}{$\begin{array}{c}\text { Specimens } \\
\text { No. }\end{array}$} & $f_{c}$ & $\sigma$ & & \multirow{2}{*}{$\sigma / \sigma_{c}$} & \multirow{2}{*}{$\tau / \sigma_{c}$} & \multirow{2}{*}{$\theta$} & \multirow[b]{2}{*}{$\sigma_{0}$} & \multirow[b]{2}{*}{$\tau_{0}$} & \multirow[b]{2}{*}{$\sigma_{0} / f_{c}$} & \multirow[b]{2}{*}{$\tau_{0} / f_{c}$} \\
\hline & $\mathrm{kg} / \mathrm{cm}^{2}$ & $\mathrm{~kg} / \mathrm{cm}^{2}$ & $\mathrm{~kg} / \mathrm{cm}^{2}$ & & & & & & & \\
\hline $\begin{array}{l}20-K \\
20-C\end{array}$ & 121 & & 25.6 & & 0.21 & 40 & 31.7 & $\begin{array}{l}20.9 \\
44.8\end{array}$ & 0.262 & $\begin{array}{l}0.370 \\
0.173\end{array}$ \\
\hline $\begin{array}{l}18-\mathrm{C} \\
18-\mathrm{K} \\
18-\mathrm{CK} 1 \\
18-\mathrm{CK} 2 \\
18-\mathrm{CK} 3\end{array}$ & 156 & $\begin{array}{r}126.0 \\
33.6 \\
63.0 \\
92.5\end{array}$ & $\begin{array}{l}22.7 \\
21.3 \\
21.2 \\
29.9\end{array}$ & $\begin{array}{l}0.808 \\
0.215 \\
0.404 \\
0.592\end{array}$ & $\begin{array}{l}0.145 \\
0.136 \\
0.200 \\
0.192\end{array}$ & $\begin{array}{l}39 \\
22 \\
19 \\
14\end{array}$ & $\begin{array}{l}42.0 \\
11.2 \\
21.0 \\
30.8\end{array}$ & $\begin{array}{l}59.3 \\
18.5 \\
23.5 \\
39.1 \\
49.9\end{array}$ & $\begin{array}{l}0.269 \\
0.072 \\
0.135 \\
0.198\end{array}$ & $\begin{array}{l}0.380 \\
0.119 \\
0.151 \\
0.250 \\
0.320\end{array}$ \\
\hline $\begin{array}{l}19-\mathrm{C} \\
19-\mathrm{K} \\
16-\mathrm{CK} 1 \\
19-\mathrm{CK} 2 \\
19-\mathrm{CK} 3\end{array}$ & 162 & $\begin{array}{r}50.4 \\
80.6 \\
101.0\end{array}$ & $\begin{array}{l}22.5 \\
25.2 \\
33.4 \\
30.7\end{array}$ & $\begin{array}{l}0.312 \\
0.497 \\
0.624\end{array}$ & $\begin{array}{l}0.139 \\
0.156 \\
0.206 \\
0.190\end{array}$ & $\begin{array}{r}39 \\
19 \\
11 \\
7\end{array}$ & $\begin{array}{l}42.0 \\
16.8 \\
26.9 \\
33.7\end{array}$ & $\begin{array}{l}59.8 \\
18.3 \\
31.4 \\
46.7 \\
53.7\end{array}$ & $\begin{array}{l}0.259 \\
0.104 \\
0.166 \\
0.208\end{array}$ & $\begin{array}{l}0.369 \\
0.113 \\
0.194 \\
0.288 \\
0.332\end{array}$ \\
\hline
\end{tabular}




\begin{tabular}{|c|c|c|c|c|c|c|c|c|c|c|}
\hline \multirow{2}{*}{$\begin{array}{l}\text { Specimens } \\
\text { No. }\end{array}$} & $f_{c}$ & $\sigma$ & $\tau$ & \multirow{2}{*}{$\sigma / \sigma_{c}$} & \multirow{2}{*}{$\tau / \sigma_{C}$} & \multirow{2}{*}{$\theta$} & \multirow{2}{*}{$\sigma_{0}$} & \multirow[b]{2}{*}{$\tau_{0}$} & \multirow{2}{*}{$\sigma_{0} / f_{c}$} & \multirow{2}{*}{$\tau_{0} / f_{c}$} \\
\hline & $\mathrm{kg} / \mathrm{cm}^{2}$ & $\mathrm{~kg} / \mathrm{cm}^{2}$ & $\mathrm{~kg} / \mathrm{cm}^{2}$ & & & & & & & \\
\hline $\begin{array}{l}17-\mathrm{C} \\
17-\mathrm{K} \\
17-\mathrm{CK} 1 \\
17-\mathrm{CK} 2 \\
17-\mathrm{CK} 3 \\
17-\mathrm{CK} 4\end{array}$ & 174 & $\begin{array}{l}16.8 \\
29.4 \\
50.5 \\
80.6\end{array}$ & $\begin{array}{l}27.0 \\
14.8 \\
24.9 \\
28.9 \\
32.4 \\
\end{array}$ & $\begin{array}{l}0.097 \\
0.169 \\
0.290 \\
0.463\end{array}$ & $\begin{array}{l}0.155 \\
0.085 \\
0.143 \\
0.166 \\
0.186\end{array}$ & $\begin{array}{l}34 \\
18 \\
21 \\
29 \\
16\end{array}$ & $\begin{array}{r}45.3 \\
5.6 \\
9.8 \\
16.8 \\
26.9\end{array}$ & $\begin{array}{l}64.0 \\
22.0 \\
14.4 \\
24.6 \\
33.5 \\
46.3\end{array}$ & $\begin{array}{l}0.260 \\
0.032 \\
0.056 \\
0.097 \\
0.155\end{array}$ & $\begin{array}{l}0.368 \\
0.127 \\
0.088 \\
0.141 \\
0.193 \\
0.266\end{array}$ \\
\hline $\begin{array}{l}\text { 8-C } \\
\text { 8-K } \\
8-\mathrm{CK} 1 \\
8-\mathrm{CK} 2 \\
8-\mathrm{CK} 3 \\
8-\mathrm{CK} 4\end{array}$ & 180 & $\begin{array}{r}14.3 \\
21.0 \\
52.0 \\
92.5 \\
129.5\end{array}$ & $\begin{array}{l}14.3 \\
14.3 \\
24.8 \\
32.0 \\
25.3\end{array}$ & $\begin{array}{l}0.116 \\
0.290 \\
0.515 \\
0.720 \\
\end{array}$ & $\begin{array}{l}0.079 \\
0.079 \\
0.138 \\
0.178 \\
0.140 \\
\end{array}$ & $\begin{array}{l}42 \\
29 \\
18 \\
17\end{array}$ & $\begin{array}{r}47.0 \\
7.0 \\
17.3 \\
30.8 \\
43.2 \\
\end{array}$ & $\begin{array}{l}66.4 \\
11.7 \\
18.9 \\
31.8 \\
50.8 \\
64.4\end{array}$ & $\begin{array}{l}0.621 \\
0.039 \\
0.096 \\
0.171 \\
0.240\end{array}$ & $\begin{array}{l}0.369 \\
0.065 \\
0.105 \\
0.177 \\
0.282 \\
0.358\end{array}$ \\
\hline $\begin{array}{l}10-\mathrm{C} \\
10-\mathrm{K} \\
10-\mathrm{CK} 1 \\
10-\mathrm{CK} 2 \\
10-\mathrm{CK} 3 \\
10-\mathrm{CK} 4 \\
\end{array}$ & 193 & $\begin{array}{r}20.2 \\
58.8 \\
79.8 \\
109.0 \\
\end{array}$ & $\begin{array}{l}10.2 \\
28.6 \\
27.6 \\
29.3 \\
37.8\end{array}$ & $\begin{array}{l}0.104 \\
0.304 \\
0.414 \\
0.565\end{array}$ & $\begin{array}{l}0.053 \\
0.148 \\
0.143 \\
0.215 \\
0.293\end{array}$ & $\begin{array}{r}48 \\
28 \\
9 \\
11 \\
12\end{array}$ & $\begin{array}{r}50.3 \\
6.7 \\
19.6 \\
26.6 \\
36.3\end{array}$ & $\begin{array}{r}71.1 \\
8.3 \\
25.2 \\
35.7 \\
44.5 \\
59.9\end{array}$ & $\begin{array}{l}0.261 \\
0.035 \\
0.102 \\
0.138 \\
0.188\end{array}$ & $\begin{array}{l}0.369 \\
0.043 \\
0.131 \\
0.185 \\
0.230 \\
0.311\end{array}$ \\
\hline $\begin{array}{l}9-\mathrm{C} \\
\text { 9-K } \\
\text { 9-CK } 1 \\
9-\mathrm{CK} 2 \\
\text { 9-CK } 3 \\
\text { 9-CK } 4\end{array}$ & 205 & $\begin{array}{r}29.4 \\
50.5 \\
101.0 \\
126.0\end{array}$ & $\begin{array}{l}25.2 \\
29.6 \\
22.5 \\
39.5 \\
37.4 \\
\end{array}$ & $\begin{array}{l}0.143 \\
0.246 \\
0.493 \\
0.614 \\
\end{array}$ & $\begin{array}{l}0.123 \\
0.144 \\
0.110 \\
0.193 \\
0.182\end{array}$ & $\begin{array}{l}43 \\
23 \\
20 \\
13\end{array}$ & $\begin{array}{r}53.3 \\
9.8 \\
16.8 \\
33.7 \\
42.0\end{array}$ & $\begin{array}{l}75.4 \\
20.5 \\
27.8 \\
30.1 \\
57.4 \\
66.7\end{array}$ & $\begin{array}{l}0.260 \\
0.048 \\
0.082 \\
0.164 \\
0.205\end{array}$ & $\begin{array}{l}0.367 \\
0.100 \\
0.136 \\
0.147 \\
0.280 \\
0.325\end{array}$ \\
\hline $\begin{array}{l}7-\mathrm{C} \\
7-\mathrm{K} \\
7-\mathrm{CK} 1 \\
77 \mathrm{CK} 2 \\
7-\mathrm{CK} 3 \\
7-\mathrm{CK} 4\end{array}$ & 232 & $\begin{array}{r}15.1 \\
50.5 \\
101.1\end{array}$ & $\begin{array}{l}28.0 \\
27.4 \\
25.5 \\
37.6 \\
31.3\end{array}$ & $\begin{array}{l}0.065 \\
0.218 \\
0.436\end{array}$ & $\begin{array}{l}0.121 \\
0.118 \\
0.110 \\
0.162 \\
0.135 \\
\end{array}$ & $\begin{array}{l}48 \\
28 \\
18\end{array}$ & $\begin{array}{r}60.7 \\
5.0 \\
16.8 \\
33.7\end{array}$ & $\begin{array}{l}86.3 \\
22.8 \\
23.4 \\
31.6 \\
56.6 \\
25.5\end{array}$ & $\begin{array}{l}0.262 \\
0.022 \\
0.072 \\
0.145\end{array}$ & $\begin{array}{l}0.372 \\
0.098 \\
0.101 \\
0.136 \\
0.244 \\
0.110\end{array}$ \\
\hline $\begin{array}{l}2-\mathrm{C} \\
2-\mathrm{K} \\
2-\mathrm{CK} 1 \\
2-\mathrm{CK} 2 \\
2-\mathrm{CK} 3\end{array}$ & 246 & $\begin{array}{l}92.5 \\
33.6 \\
84.1 \\
58.8\end{array}$ & $\begin{array}{l}16.7 \\
29.7 \\
32.2 \\
32.0\end{array}$ & $\begin{array}{l}0.375 \\
\\
0.136 \\
0.341 \\
0.240 \\
\end{array}$ & $\begin{array}{l}0.068 \\
0.120 \\
0.130 \\
0.130\end{array}$ & 20 & $\begin{array}{l}30.8 \\
11.2 \\
28.0 \\
19.6\end{array}$ & $\begin{array}{l}43.6 \\
13.6 \\
28.9 \\
47.5 \\
38.1\end{array}$ & $\begin{array}{l}0.125 \\
0.046 \\
0.114 \\
0.080\end{array}$ & $\begin{array}{l}0.177 \\
0.053 \\
0.118 \\
0.193 \\
0.155\end{array}$ \\
\hline $\begin{array}{l}3-\mathrm{C} \\
3-\mathrm{K} 1 \\
3-\mathrm{K} 2\end{array}$ & 256 & & $\begin{array}{l}14.3 \\
12.0\end{array}$ & & $\begin{array}{l}0.056 \\
0.047 \\
\end{array}$ & & 66.7 & $\begin{array}{r}94.2 \\
11.7 \\
9.8\end{array}$ & 0.261 & $\begin{array}{l}0.368 \\
0.046 \\
0.038\end{array}$ \\
\hline $\begin{array}{l}4-\mathrm{C} \\
4-\mathrm{K} \\
4-\mathrm{CK} 1 \\
4-\mathrm{CK} 2\end{array}$ & 259 & $\begin{array}{l}14.3 \\
18.5 \\
79.8\end{array}$ & $\begin{array}{l}15.0 \\
20.3 \\
21.6\end{array}$ & $\begin{array}{l}0.553 \\
0.071 \\
0.308\end{array}$ & $\begin{array}{l}0.058 \\
0.078 \\
0.084\end{array}$ & $\begin{array}{l}50 \\
32 \\
19 \\
\end{array}$ & $\begin{array}{r}47.7 \\
6.2 \\
26.6 \\
\end{array}$ & $\begin{array}{l}67.3 \\
12.2 \\
18.7 \\
41.2 \\
\end{array}$ & $\begin{array}{l}0.184 \\
0.024 \\
0.103\end{array}$ & $\begin{array}{l}0.260 \\
0.047 \\
0.072 \\
0.159 \\
\end{array}$ \\
\hline $\begin{array}{l}5-\mathrm{C} \\
5-\mathrm{K} \\
5-\mathrm{CK} 1\end{array}$ & 270 & $\begin{array}{l}126.0 \\
191.0\end{array}$ & $\begin{array}{l}26.4 \\
12.4\end{array}$ & $\begin{array}{l}0.467 \\
0.710\end{array}$ & $\begin{array}{l}0.098 \\
0.046\end{array}$ & $\begin{array}{r}50 \\
8 \\
\end{array}$ & $\begin{array}{l}42.0 \\
63.7\end{array}$ & $\begin{array}{l}59.3 \\
21.5 \\
90.5\end{array}$ & $\begin{array}{l}0.156 \\
0.236\end{array}$ & $\begin{array}{l}0.220 \\
0.080 \\
0.335\end{array}$ \\
\hline $\begin{array}{l}6-\mathrm{C} \\
6-\mathrm{K} \\
6-\mathrm{CK} 1 \\
6-\mathrm{CK} 2 \\
6-\mathrm{CK} 3\end{array}$ & 277 & $\begin{array}{l}15.1 \\
93.3 \\
63.0\end{array}$ & $\begin{array}{l}16.7 \\
23.4 \\
36.4 \\
29.4 \\
\end{array}$ & $\begin{array}{l}0.054 \\
0.377 \\
0.228\end{array}$ & $\begin{array}{l}0.060 \\
0.084 \\
0.132 \\
0.106\end{array}$ & $\begin{array}{l}47 \\
30 \\
15 \\
18\end{array}$ & $\begin{array}{r}71.7 \\
5.0 \\
31.1 \\
21.0\end{array}$ & $\begin{array}{r}101.3 \\
13.6 \\
20.4 \\
53.0 \\
38.2\end{array}$ & $\begin{array}{l}0.259 \\
\\
0.018 \\
0.112 \\
0.076\end{array}$ & $\begin{array}{l}0.365 \\
0.049 \\
0.074 \\
0.191 \\
0.138\end{array}$ \\
\hline $\begin{array}{l}1-\mathrm{C} \\
1-\mathrm{K}\end{array}$ & 296 & 207.0 & 18.1 & $\begin{array}{l}0.700 \\
0.061 \\
\end{array}$ & & & 69,0 & $\begin{array}{l}97.5 \\
14.8\end{array}$ & 0.233 & $\begin{array}{l}0.329 \\
0.500\end{array}$ \\
\hline $\begin{array}{l}16-\mathrm{C} \\
16-\mathrm{K} \\
16-\mathrm{CK} 1 \\
1-6 \mathrm{CK} 2 \\
16-\mathrm{CK} 3 \\
16-\mathrm{CK} 4\end{array}$ & 316 & $\begin{array}{r}50.5 \\
126.0 \\
109.0 \\
134.5\end{array}$ & $\begin{array}{l}26.4 \\
24.7 \\
49.8 \\
41.8 \\
26.9\end{array}$ & $\begin{array}{l}0.160 \\
0.400 \\
0.345 \\
0.426\end{array}$ & $\begin{array}{l}0.835 \\
0.078 \\
0.158 \\
0.132 \\
0.085\end{array}$ & $\begin{array}{l}40 \\
17 \\
17 \\
13 \\
14\end{array}$ & $\begin{array}{l}81.7 \\
16.8 \\
42.0 \\
36.3 \\
44.8\end{array}$ & $\begin{array}{r}115.4 \\
21.5 \\
31.2 \\
71.9 \\
61.6 \\
67.0\end{array}$ & $\begin{array}{l}0.258 \\
0.053 \\
0.133 \\
0.115 \\
0.142\end{array}$ & $\begin{array}{l}0.366 \\
0.068 \\
0.099 \\
0.228 \\
0.195 \\
0.212 \\
\end{array}$ \\
\hline $\begin{array}{l}14-\mathrm{C} \\
14-\mathrm{K} \\
14-\mathrm{CK} 1 \\
14-\mathrm{CK} 2 \\
14-\mathrm{CK} 3 \\
14-\mathrm{CK} 4 \\
\end{array}$ & 348 & $\begin{array}{l}10.1 \\
42.0 \\
84.1 \\
71.5 \\
\end{array}$ & $\begin{array}{l}25.7 \\
37.9 \\
37.0 \\
31.6 \\
26.2\end{array}$ & $\begin{array}{l}0.029 \\
0.121 \\
0.241 \\
0.205 \\
\end{array}$ & $\begin{array}{l}0.074 \\
0.109 \\
0.106 \\
0.091 \\
0.075\end{array}$ & $\begin{array}{l}47 \\
16 \\
25 \\
10 \\
12\end{array}$ & $\begin{array}{r}90.0 \\
3.4 \\
14.0 \\
28.0 \\
23.8 \\
\end{array}$ & $\begin{array}{r}127.1 \\
20.9 \\
31.3 \\
36.1 \\
47.3 \\
39.9 \\
\end{array}$ & $\begin{array}{l}0.259 \\
0.010 \\
0.040 \\
0.081 \\
0.069 \\
\end{array}$ & $\begin{array}{l}0.360 \\
0.060 \\
0.090 \\
0.104 \\
0.136 \\
0.115 \\
\end{array}$ \\
\hline $\begin{array}{l}11-\mathrm{C} \\
11-\mathrm{K} \\
11-\mathrm{CK} 1 \\
11-\mathrm{C}^{\prime}\end{array}$ & 357 & $\begin{array}{r}160.0 \\
84.1\end{array}$ & $\begin{array}{l}24.8 \\
28.6\end{array}$ & $\begin{array}{l}0.045 \\
0.236\end{array}$ & $\begin{array}{l}0.069 \\
0.080\end{array}$ & $\begin{array}{l}36 \\
55\end{array}$ & $\begin{array}{l}53.3 \\
28.0 \\
93.3 \\
\end{array}$ & $\begin{array}{r}75.4 \\
20.2 \\
46.0 \\
131.9 \\
\end{array}$ & $\begin{array}{l}0.149 \\
0.079 \\
0.261 \\
\end{array}$ & $\begin{array}{l}0.211 \\
0.057 \\
0.129 \\
0.370 \\
\end{array}$ \\
\hline $\begin{array}{l}15-\mathrm{C} \\
15-\mathrm{K} \\
15-\mathrm{CK} 1 \\
15-\mathrm{CK} 2 \\
\end{array}$ & 369 & $\begin{array}{r}126.0 \\
63.0 \\
\end{array}$ & $\begin{array}{l}18.1 \\
39.1 \\
35.7 \\
\end{array}$ & $\begin{array}{l}0.341 \\
0.171 \\
\end{array}$ & $\begin{array}{l}0.049 \\
0.106 \\
0.097 \\
\end{array}$ & $\begin{array}{l}50 \\
24 \\
29 \\
\end{array}$ & $\begin{array}{r}93.3 \\
42.0 \\
21.0 \\
\end{array}$ & $\begin{array}{r}131.9 \\
14.8 \\
65.2 \\
41.6 \\
\end{array}$ & $\begin{array}{l}0.253 \\
0.114 \\
0.057 \\
\end{array}$ & $\begin{array}{l}0.357 \\
0.040 \\
0.177 \\
0.113 \\
\end{array}$ \\
\hline $\begin{array}{l}12-\mathrm{C} \\
12-\mathrm{K} \\
12-\mathrm{CK} 1 \\
12-\mathrm{CK} 2 \\
12-\mathrm{CK} 3 \\
12-\mathrm{CK} 4 \\
13-\mathrm{C}\end{array}$ & 395 & $\begin{array}{l}21.0 \\
40.4 \\
60.5 \\
90.8 \\
\end{array}$ & $\begin{array}{l}21.0 \\
30.9 \\
22.6 \\
32.8 \\
30.8 \\
\end{array}$ & $\begin{array}{l}0.053 \\
0.102 \\
0.153 \\
0.230 \\
\end{array}$ & $\begin{array}{l}0.053 \\
0.078 \\
0.057 \\
0.083 \\
0.078 \\
\end{array}$ & $\begin{array}{l}56 \\
32 \\
26 \\
23 \\
20 \\
\end{array}$ & $\begin{array}{r}100.0 \\
7.0 \\
13.5 \\
20.2 \\
30.3 \\
103.3 \\
\end{array}$ & $\begin{array}{r}141.3 \\
117.1 \\
27.1 \\
26.5 \\
39.1 \\
49.6 \\
146.0\end{array}$ & $\begin{array}{l}0.253 \\
0.018 \\
0.034 \\
0.051 \\
0.077 \\
0.257\end{array}$ & $\begin{array}{l}0.358 \\
0.043 \\
0.069 \\
0.067 \\
0.100 \\
0.126 \\
0.363 \\
\end{array}$ \\
\hline $\begin{array}{l}13-\mathrm{C} \\
13-\mathrm{K} \\
13-\mathrm{CK} 1 \\
13-\mathrm{CK} 2 \\
13-\mathrm{CK} 3 \\
13-\mathrm{CK} 4 \\
\end{array}$ & 402 & $\begin{array}{r}30.3 \\
50.5 \\
117.6 \\
134.5 \\
\end{array}$ & $\begin{array}{l}22.2 \\
35.2 \\
31.7 \\
42.4 \\
37.6 \\
\end{array}$ & $\begin{array}{l}0.075 \\
0.126 \\
0.293 \\
0.335 \\
\end{array}$ & $\begin{array}{l}0.055 \\
0.087 \\
0.079 \\
0.106 \\
0.094 \\
\end{array}$ & $\begin{array}{r}42 \\
26 \\
24 \\
17 \\
8 \\
\end{array}$ & \begin{tabular}{r|}
103.3 \\
10.1 \\
16.8 \\
39.2 \\
44.8 \\
\end{tabular} & $\begin{array}{r}146.0 \\
18.1 \\
32.1 \\
35.1 \\
65.3 \\
70.4 \\
\end{array}$ & $\begin{array}{l}0.257 \\
0.025 \\
0.042 \\
0.098 \\
0.112 \\
\end{array}$ & $\begin{array}{l}0.363 \\
0.045 \\
0.080 \\
0.088 \\
0.163 \\
0.175 \\
\end{array}$ \\
\hline
\end{tabular}


1. H. Yoshida : Architecture Library, (KOUTOUKENTIKUGAKU No. 4) 1933.

2. S. Ito : Strength of concrete under Combined Stresses. Proceeding 3rd Jap. Cong. Test Mat., 1959.

3. W.A. Scoble : Phil. Mag., 19. 1910.

4. T.V. Karman : Forsch, Arb. V.D.I. Heft 118, 1912.

5. R. Ros \& A. Eichinger : Proc. 2nd Intern. Congress for Applied Mechanics, Zürich, 1926.

6. A. Griffith : Phil. Trans. Royal. Soc. London, Vol. 221, pp. 163-198 (1920-21)

7. D. Fischer: Thesis for the Degree of PH. D. Univ., of London, 1950.

8. H.J. Cowan: Fourth Congress Int. Assoc. Br. and Struct. Eng., Preliminary Publication (1952). Mag. of Concr. Res., No. 14 (Dec. 1953).

9. A. Brandtzaeg: Det Kgl. Norske Videnskabers Selskabs Skrifter, Nr. 2 (1927).

10. A. Freudenthal : Proc. First U.S. Nat. Congr. of Appl. Mech., pp. 641-646. Chicago (1951).

11. D. McKenry \& J. Karni : Journal of A.C.I. April 1958.

12. B. Bresler \& K.S. Pister : Journal of A.C.I. Sep. 1958.

13. A. Leon: Beton u. Eisen, Vol. 34, pp. 130-135 (1934-35).

14. F. Schleicher: Zamm, Vol. 6, pp. 199-216 (1926).

15. C. Torre : Oster. Ing. Archv. Vol. 1, pp. 316-342 (1947).

16. G. Wastlund : Nya rön Angaende Betongens Grundlaggande Halbfasthetsegenskaper. Vol. 3. (1945).

17. H. Nylander: Statens Kommitte för Byggnadsforskning, Meddelanden No. 3. (1945).

18. A.K. Malmeister, \& K.K. Shkerbelis : Issledobanija po Betony i Zhelezobetonu. Akademija Nauk Latvijskoj SSR Institut Arkhitektury i Stroiteljstva. (Piga 1957).

19. Y. Tsuboi \& Y. Suenaga: Transactions of the A.I.J. No. 63. (1959).

20. A. Nadai : Theory of Flow and Fracture of Solids, McGraw Hill, New York (1950).

21. R. Hill : The Mathematical Theory of Plasticity, Clarendon Press, Oxford, 1950.

22. W. Prager \& P.G. Hodge : Theory of Perfectly Plastic Solids. (1951)

\section{組合せ応力のもとに於ける無筋コンクリートの破壊に関する実験的研究（第 3 報）}

\section{概 要}

この研究は Combined Stress をうけた場合の鉄筋コンクリ

一ト部材の破壊法則を確め, かつ構造物設計一の破壊論の適用 を目的としている。試験沖空円筒型試験体に相互に直角の圧 縮と引張を作用させた場合と軸圧縮とねじりを作用させた場合 の二部門について行つている。

実験資料は八面体応力理論によつて解折され，一次式の直線 関係で表わされた。これらの解折結果は圧縮と引張及び圧縮と ねじりの試験とむよく一致している。猶圧縮とねじり試験に於

\begin{tabular}{|c|c|c|c|}
\hline 正会 員 & 坪 & 井 & 善 \\
\hline 同 & 末 & 标 & $\pi$ \\
\hline
\end{tabular}

て瓜縮応力に対する垂直応力 $(\sigma)$ とせん断応力 $(\tau)$ の相関々係 は次式で表わされる。

$$
\frac{\tau}{\sigma_{c}}=\sqrt{-0.104\left(\frac{\sigma}{\sigma_{c}}\right)^{2}+0.095\left(\frac{\sigma}{\sigma_{c}}\right)+0.0089}
$$

これら実験結果は単純压縮から単純ねじりの場合の二軸応力 状態にのみ適用される。二軸及び三軸圧縮状態には適用出来な w。

* 東大教授 工博 $* *$ 東大大学院 